The Asia-Pacific Research and Training Network on Trade (ARTNeT) is an open regional network of research and academic institutions specializing in international trade policy and facilitation issues. IDRC, UNCTAD, UNDP, ESCAP and WTO, as core network partners, provide substantive and/or financial support to the network. The Trade and Investment Division of ESCAP, the regional branch of the United Nations for Asia and the Pacific, provides the Secretariat of the network and a direct regional link to trade policymakers and other international organizations.

The ARTNeT Working Paper Series disseminates the findings of work in progress to encourage the exchange of ideas about trade issues. An objective of the series is to publish the findings quickly, even if the presentations are less than fully polished. ARTNeT Working Papers are available online at www.artnetontrade.org. All material in the Working Papers may be freely quoted or reprinted, but acknowledgment is requested, together with a copy of the publication containing the quotation or reprint. The use of the working papers for any commercial purpose, including resale, is prohibited.

\section{Disclaimer:}

The designations employed and the presentation of the material in this Working Paper do not imply the expression of any opinion whatsoever on the part of the Secretariat of the United Nations concerning the legal status of any country, territory, city or area, or of its authorities, or concerning the delimitation of its frontiers or boundaries. Where the designation "country or area" appears, it covers countries, territories, cities or areas. Bibliographical and other references have, wherever possible, been verified. The United Nations bears no responsibility for the availability or functioning of URLs. The views expressed in this publication are those of the author(s) and do not necessarily reflect the views of the United Nations. The opinions, figures and estimates set forth in this publication are the responsibility of the author(s), and should not necessarily be considered as reflecting the views or carrying the endorsement of the United Nations. Any errors are the responsibility of the author(s). The mention of firm names and commercial products does not imply the endorsement of the United Nations. 


\title{
Prospects for enhancing energy security in Asia and the Pacific through regional trade
}

\author{
Joong-Wan Cho*, Rajan Sudesh Ratna**, Vivian Leung Shi Min***
}

Please cite this paper as: Joong-Wan Cho, Rajan Sudesh Ratna, Vivian Leung Shi Min (2015), Prospects for enhancing energy security in Asia and the Pacific through regional trade

ARTNeT Working Paper Series No. 153, 2015, Bangkok, ESCAP.

Available at www.artnetontrade.org

\begin{abstract}
*Joong-Wan Cho is Chief, Asia Pacific Trade Agreement Unit, Trade and Investment Division, ESCAP. ${ }^{* *}$ Rajan Sudesh Ratna is an Economic Affairs Officer, Trade Policy and Analysis Section, Trade and Investment Division, ESCAP. ${ }^{* * *}$ Vivian Leung Shi Min was an Intern in Trade and Investment Division, ESCAP. The authors are grateful to Ravi Ratnayake and Mia Mikic for their valuable comments and wish to acknowledge excellent assistance from Pooja Tripathi in editing and formatting this working paper. The authors are also grateful to the ARTNeT Secretariat for technical support in disseminating this paper. Any errors that remain are the sole responsibility of the authors.
\end{abstract}




\begin{abstract}
Growing demand for raw materials and the expansion of the productive capacity of emerging economies have exacerbated the region's high resource dependence, especially in energy, such as fossil fuels. A growth in energy demand, coupled with the high price volatility and dependence on fossil fuels, has made efforts for energy security more challenging than before. The Asia-Pacific region as a whole has increased its share of global commodity imports, across all sectors (minerals and metals, fuels and agriculture) over the last five years (2009 to 2013), from $26 \%$ to $30 \%$, based on nominal values. Growth in energy demand, coupled with the increasing price volatility and dependence on fossil fuels, has made efforts for energy security more challenging than before.
\end{abstract}

The Asia-Pacific economies hold vast amounts of fossil and non-fossil energy resources. As a region, it is a net exporter of coal, natural gas (through the pipeline), and electricity, but a net importer of oil and liquefied natural gas (LNG). Owing to accelerated levels of economic development, region's demand continued to grow. This increased demand is not being met with a sufficient rise in production, leading to reduced exports and increased import demand. Despite holding vast coal and natural gas reserves, demand for fossil fuel in Asia and the Pacific is increasingly being met by imports with long term effect on its trade balance.

To enhance energy security, which is essential for inclusive and sustainable growth, countries of Asia-Pacific will have to strengthen energy cooperation, build regional connectivity, and invest in adequate infrastructure. Growing import dependency coupled with emergent regionalism has certainly enhanced the prospects for regional energy cooperation and integration of the energy sector, which can enhance the possibility of regional energy security. However, due to its diverse nature, such cooperation is confined to national initiatives rather than at a pan Asia-Pacific or sub-regional levels.

The paper examines the prospects for enhanced energy security through regional energy trade and integration by exploring the case of the Asia-Pacific Trade Agreement (APTA). The paper concludes by stating that regional cooperation for achieving energy security collectively is a viable alternative to traditional individual or bilateral attempts and that the Asia-Pacific Trade Agreement is an ideal vehicle for providing energy security through enhanced trade due to tariff concessions to be offered on energy products and also through expansion of its membership to the energy supplying countries.

Keywords: Energy trade, Energy security, Exports, Liberalization, Regional trade, APTA, Preferential trade,

JEL classification: $F$ 15, F 18, Q 37 and Q 41 


\section{Contents}

1. Introduction

2. Trade and energy 3

2.1. Importance of energy trade in Asia and the Pacific 4

2.2. Oil trade 5

$\begin{array}{ll}\text { 2.3. Natural gas trade } & 7\end{array}$

2.4. Natural gas prices $\quad 10$

2.5. Coal trade 11

2.6. Cross border electricity trade 13

2.7. Summary of key energy exporting and importing countries 16

3. Regional trade and energy security 18

3.1. Efforts taken for energy cooperation and security 19

3.2. Energy security and trade implications for regional trade agreements - the case of the Asia-Pacific Trade Agreement $\quad 20$

3.3. Import of gas by APTA members 26

3.4. Import of oil by APTA members 28

3.5. Import of coal by APTA members 30

3.6. Import of electricity by APTA members 32

3.7. Implication for accession of selected Central and South Asian countries to APTA 35

$\begin{array}{ll}\text { 4. Conclusion } & 38\end{array}$

$\begin{array}{lr}\text { References } & 40\end{array}$

Figures

Figure 1: Contribution of Asia-Pacific economies to world fossil fuel resources 2

Figure 2: Energy self-sufficiency in the Asia-pacific region 5

Figure 3: Top crude oil importers and exporters in the Asia-Pacific region, 2006-2010 6

Figure 4: Sources of Asia-Pacific oil inputs, 2008 and 2012

Figure 5: Liquefied natural gas imports of select Asia-Pacific economies, 2012 (in billion cubic metres) 9

Figure 6: Liquefied natural gas exports of select Asia-Pacific economies, 2012 (in billion cubic metres)

Figure 7: Natural gas imports and exports by pipeline of select Asia-Pacific economies, 
2012 (in billion cubic metres)

Figure 8: Natural gas prices, 2013

Figure 9: Global and ESCAP Coal Trade, 2007-2011 (in million short tons) 12

Figure 10: Growth of coal exports in key Asia-Pacific economies, 2007-2011 (in thousand short tons) 13

Figure 11: Global and Asia-Pacific electricity trade, 2008-2010 (in billion kilowatt/hour) 14

Figure 12: Electricity trade of key Asia-Pacific economies, 2010 (in billion kilowatt/hour) 14

Figure 13: Cross-border electricity trade in the Asia-Pacific region during 2008-2010 15

Figure 14: Fossil fuel reserves of key Central and South Asian countries 23

Figure 15: People without access to electricity in the Asia-Pacific region, 2012

Figure 16: Sources of APTA members' gas imports 26

Figure 17: Sources of APTA members' oil imports 28

Figure 18: Sources of APTA members' coal imports 31

Figure 19: Imports of electricity for participating members of the Asia-Pacific Trade

Agreement

Figure 20: Household electricity tariffs for selected ESCAP member states,

September 2010

Figure 21: Energy efficiency and economic competitiveness, 2010

\section{Tables}

Table 1: Top primary (non-renewable) and secondary energy exporters and importers in Asia and the Pacific $\quad 16$

Table 2: Exports and imports of energy for some Asia-Pacific countries in 2012* 17

Table 3: Top renewable energy exporters and importers in Asia-Pacific 18

Table 4: Energy concessions given under the Asia-Pacific Trade Agreement in the fourth round negotiations $\quad 22$

Table 5: Accession process to Asia-Pacific Trade Agreement 35 


\section{Introduction}

Trade and investment are engines of growth for Asia and the Pacific. In 2012, the region surpassed Europe to become the world's largest trading region. The general decline in import demand in developed countries continues to fuel the growth of South-South trade, further strengthening the role of Asia-Pacific as most of South-South trade is contributed by this region. Therefore, intraregional exports experienced an increase in the total share of exports of these countries from $40 \%$ to $51 \%$ in the period from 2000 to 2012 (ESCAP, 2014). However, the merchandise trade in Asia and the Pacific in 2015 continues to face significant challenges due to the regional as well as global macroeconomic outlook. ESCAP (2015a) estimated that export receipts of Asian and Pacific economies grew sluggishly, at a rate of $2.5 \%$ in 2014 , while imports declined by $1.2 \%$.

Growing demand for raw materials and the expansion of the productive capacity of emerging economies have exacerbated the region's high resource dependence, especially in energy resources, such as fossil fuels. The Asia-Pacific region as a whole has increased its share of global commodity imports, across all sectors (minerals and metals, fuels and agriculture) over the last five years (2009 to 2013), from 26\% to 30\% (ESCAP 2015b and 2015c). The region's rising import bill for energy and commodities worsened its trade deficit, resulting in a net deficit with the rest of the world in 2012 (ESCAP, 2013a). Thus, growth in energy demand, coupled with the increasing price volatility and dependence on fossil fuels, has made efforts for energy security more challenging than before. Between 2011 and 2013, the import share of petroleum products in the Asia-Pacific region remained at $16 \%$, while the export share declined from $12 \%$ to $11 \%$. Furthermore, growing demand has raised the price of energy resources in the last few years. ${ }^{1}$ The overall impact of falling oil prices depends on the nature of oil-dependence (oil-importing or oil-exporting) of economies (ESCAP 2015d). ADB (2014) estimated that net oil importers in the region could see an additional $0.5 \%$ growth in 2015 GDP if oil prices remain low. The low oil prices also lowered inflation rates and present opportunities for importers such as Indonesia and India to reform their programs on fuel subsidy. For oil-exporting countries, such as the Russian Federation and other Central Asia countries, growth would be negatively impacted depending on the role of the energy sector in the national economy.

\footnotetext{
${ }^{1}$ With the exception of fall in oil prices. By early 2015 the international oil prices drastically declined $47 \%$ and then rebounded in a bit in February 2015. (Source: EIA, 2015).
} 
The Asia-Pacific economies ${ }^{2}$ hold vast amounts of fossil and non-fossil energy resources. As a region, it is a net exporter of coal, natural gas (through the pipelines), and electricity, but a net importer of oil and liquefied natural gas (LNG). Owing to accelerated levels of economic development, internal demand is constantly rising in the region. This increase is not being met with a sufficient rise in production, leading to reduced exports and even higher pressure for imports. Despite holding vast coal and natural gas reserves (figure 1), demand for fossil fuel in Asia and the Pacific is increasingly being met by imports and its trade surplus will be reduced over time. The Asian Development Bank (ADB) expects net imports ${ }^{3}$ of fossil fuels (oil, coal, and natural gas) in the Asia-Pacific region to nearly double from 830.5 million ton of oil equivalent (Mtoe) in 2010 to 1,515.5 Mtoe in 2035 (ADB, 2013).

\section{Figure 1: Contribution of Asia-Pacific economies to world fossil fuel resources}

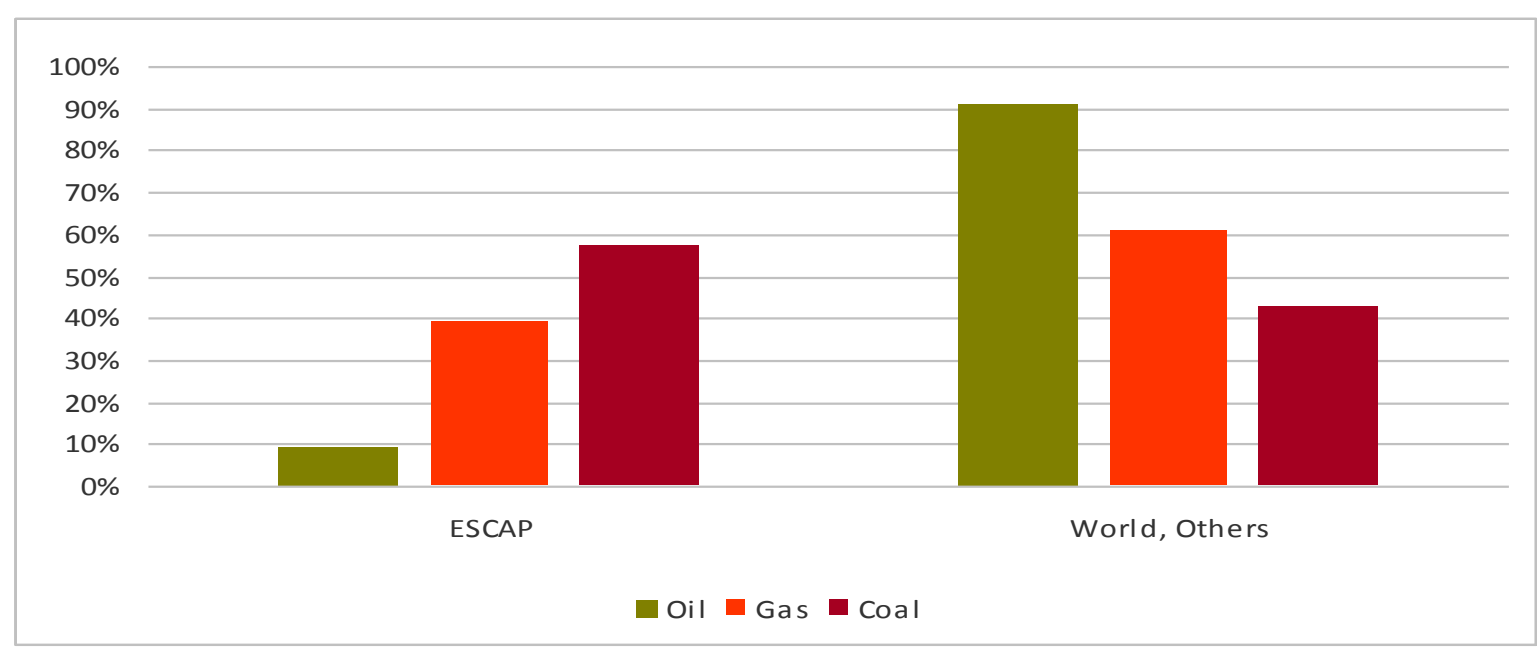

Note: Oil and natural gas reserves as of 1 January 2012; coal reserves as of 31 December 2008.

Source: EIA International Energy Statistics, http://www.eia.gov/cfapps/ipdbproject/IEDIndex3.cfm (accessed November 2013).

Asia-Pacific economies face greater challenges relating to energy security, ${ }^{4}$ which is essential for inclusive and sustainable growth. Without greater energy cooperation, building regional connectivity, providing adequate infrastructure and regional integration, energy security will remain a distant objective for many economies. Growing import dependency coupled with emergent regionalism has certainly enhanced the prospects for regional energy

\footnotetext{
${ }^{2}$ For this paper Asia-Pacific economies refer to countries and territories of the five subregions of ESCAP. Please refer to www.unescap.org/about/subregional-activities for more details.

${ }^{3}$ Net Imports = Imports - Exports.

${ }^{4}$ IEA defines energy security as the uninterrupted availability of energy sources at an affordable price. Energy security has many aspects: long-term energy security mainly deals with timely investments to supply energy in line with economic developments and environmental needs. On the other hand, short-term energy security focuses on the ability of the energy system to react promptly to sudden changes in the supply-demand balance. (http://www.iea.org/topics/energysecurity/ )
} 
cooperation and integration of the energy sector, which can enhance the possibility of regional energy security. However, due to its diverse nature, such cooperation is confined to national initiatives rather than at a pan Asia-Pacific or a regional level.

The paper examines the prospects for enhanced energy security through regional energy trade and integration. In particular, the paper examines the case of the Asia-Pacific Trade Agreement, a preferential trade agreement in goods which comprises as members China, Bangladesh, India, the Lao People's Democratic Republic, Mongolia ${ }^{5}$, the Republic of Korea and Sri Lanka.

After Introduction, Part 2 first provides an overview of energy trade in Asia and the Pacific, with a focus on primary energy commodities-oil, coal, natural gas - and the cross-border trade of electricity. The analysis uses published data on energy trade and literature reviews on energy trade, including recent projections. It then analyzes the structure and evolution of trade in primary energy commodities, cross-border electricity and climate-smart goods and technologies within and from the ESCAP subregions. The focus is on flows of oil, natural gas (through pipeline and LNG), coal, electricity, and climate-smart goods and technologies from, to, and within the ESCAP region. Analysis of part 2 closes with a summary of the key points highlighting the main energy exporters and importers, as well as the value of this trade in energy resources to that country's economy, using both gross domestic product (GDP) and overall merchandise exports and imports as basis of comparison.

Part 3 focuses on the analysis of trade of energy under regional frameworks, specifically APTA. This part also provides a broad overview of the existing initiatives for energy cooperation. Despite the genuine interest and efforts taken by certain countries and regions to deepening energy cooperation, much still needs to be done. The case of the Asia-Pacific Trade Agreement is examined to understand the energy demands of APTA members. Based on their demand, the subsequent sections examine how the APTA members can gain from their engagement with the Central Asian economies in their endeavor to energy security. The paper examines the sources and destinations of the different forms of energy traded by individual members to the Asia-Pacific Trade Agreement and the potential for energy trade between the Agreement members and the individual economies of Central Asia through the regional trade agreement of Asia-Pacific Trade Agreement. It points to mutual benefits from a partnership between members of the Asia-Pacific Trade Agreement and the economies of Central Asia.

\footnotetext{
${ }^{5}$ Mongolia has just acceded to APTA and is in a process of ratifying the agreement.
} 
The paper concludes by stating that regional cooperation for achieving energy security collectively is a viable alternative to traditional individual or bilateral attempts and that the Asia-Pacific Trade Agreement is an ideal vehicle in providing energy security through enhanced trade due to tariff concessions to be offered on energy products and also through expansion of its membership to the energy supplying countries.

\section{Trade and energy}

\subsection{Importance of energy trade in Asia and the Pacific}

Trade in energy balances the differences in energy resource endowments among countries. International trade helps to meet the energy demands of an energy-deficient country as it can import the resources, while increasing the national income of energy-exporting countries as well. The extra resources generated from exports can be used to achieve their diversification objectives. In fact, countries with surplus energy resources tend to be highly dependent on energy exports, making it crucial to secure demand in the same way that energy import-dependent countries need to secure their energy sources.

In its World Energy Outlook 2013, the International Energy Agency (IEA) stated that global energy trade had re-oriented from the Atlantic basin to the Asia-Pacific region (IEA, 2013). As shown in figure 2, the economies in the northern and southern parts of the region are generally energy self-sufficient with the economies in the eastern and western parts more prone to rely on exports to meet their energy needs.

Countries may try to achieve self-sufficiency in secondary (electricity) and refined energy, at the very least, but this endeavor is almost impossible owing to the massive infrastructure costs that such a venture would entail. In addition, availability of the latest technology to limit damage to the environment will be a major challenge for them, as they would need to adopt sustainable energy production and consumption practices. Energy sufficiency does not immediately guarantee equal access of energy across the countries or that power demand would be adequately met due to infrastructure, geography, and other structural challenges. Hence, promoting and diversifying energy trade arrangements is pivotal to securing energy security to address both external and internal imbalances for any economy. 
Figure 2: Energy self-sufficiency in the Asia-Pacific region

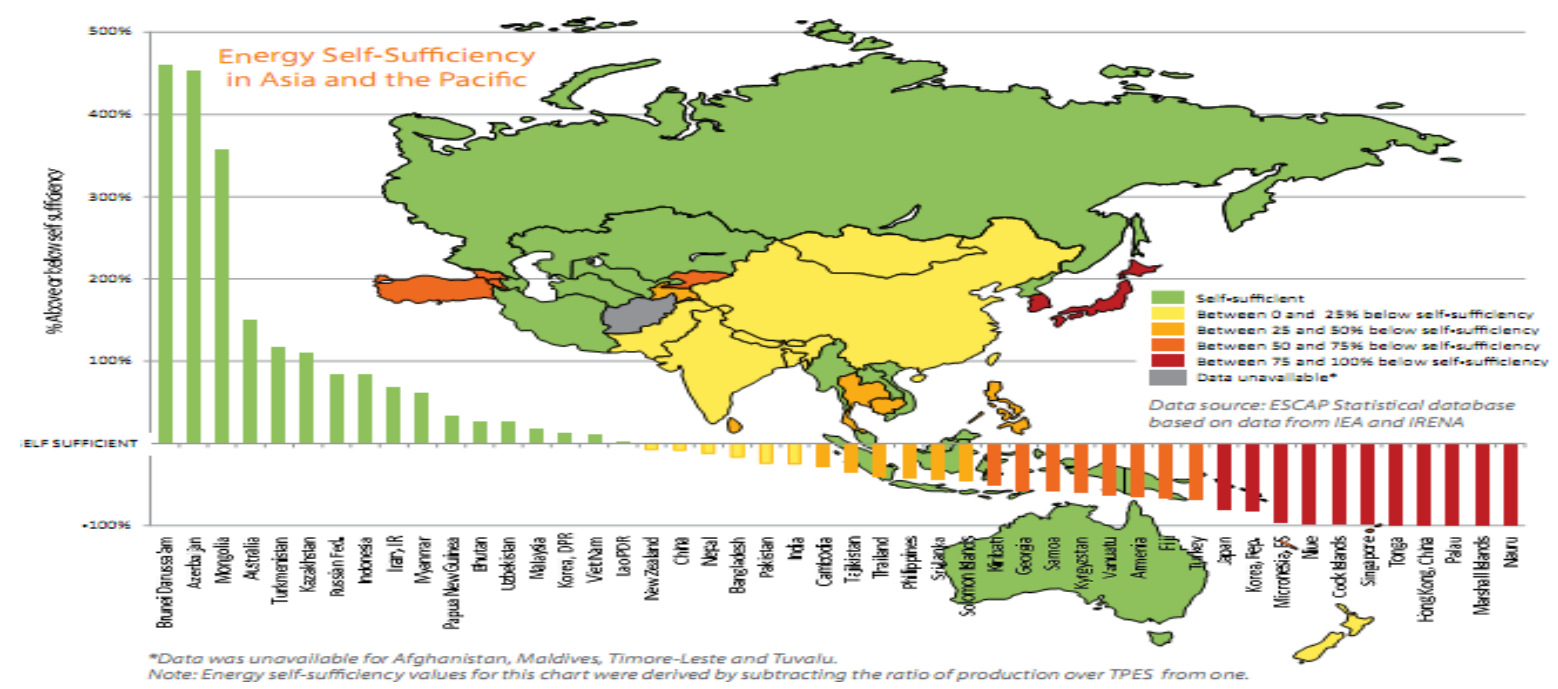

Source: ESCAP Statistical Perspectives, 2013.

The imports of energy by the Asia-Pacific region have been constantly increasing which is mainly driven by the rise in imports of the East and South Asia economies. Promoting energy trade on preferential terms, therefore, could be one of the steps towards providing a better opportunity for energy security in the region. Addressing these issues would be important for economies in the region in order to strive for the sustainable development goals in the post-2015 era.

\subsection{Oil trade}

Oil is a concentrated energy source of strategic considerations, especially for transportation. Despite considerable interest in exploring the use of other energy sources for transportation, these initiatives have not taken off on a large scale because of oil's intrinsic advantage over other energy resources; oil is liquid, making it the most economically competitive and convenient energy source. With a $34 \%$ share of global energy demand, oil remains the reference energy (Favennec 2011).

The Asia-Pacific region's rapid growth and increasing consumption has led to a rise in demand for energy. The region has the largest trade deficit in oil. According to the EIA International Energy Statistics, Asia-Pacific crude oil imports of 18,785thousand barrels per day in 2010 accounted for $43 \%$ of global oil imports in 2010, while the region's oil exports of 11,152 thousand barrels per day represented $26 \%$ of the world's total. 
Figure 3: Top crude oil importers and exporters in the Asia-Pacific region, 2006-2010
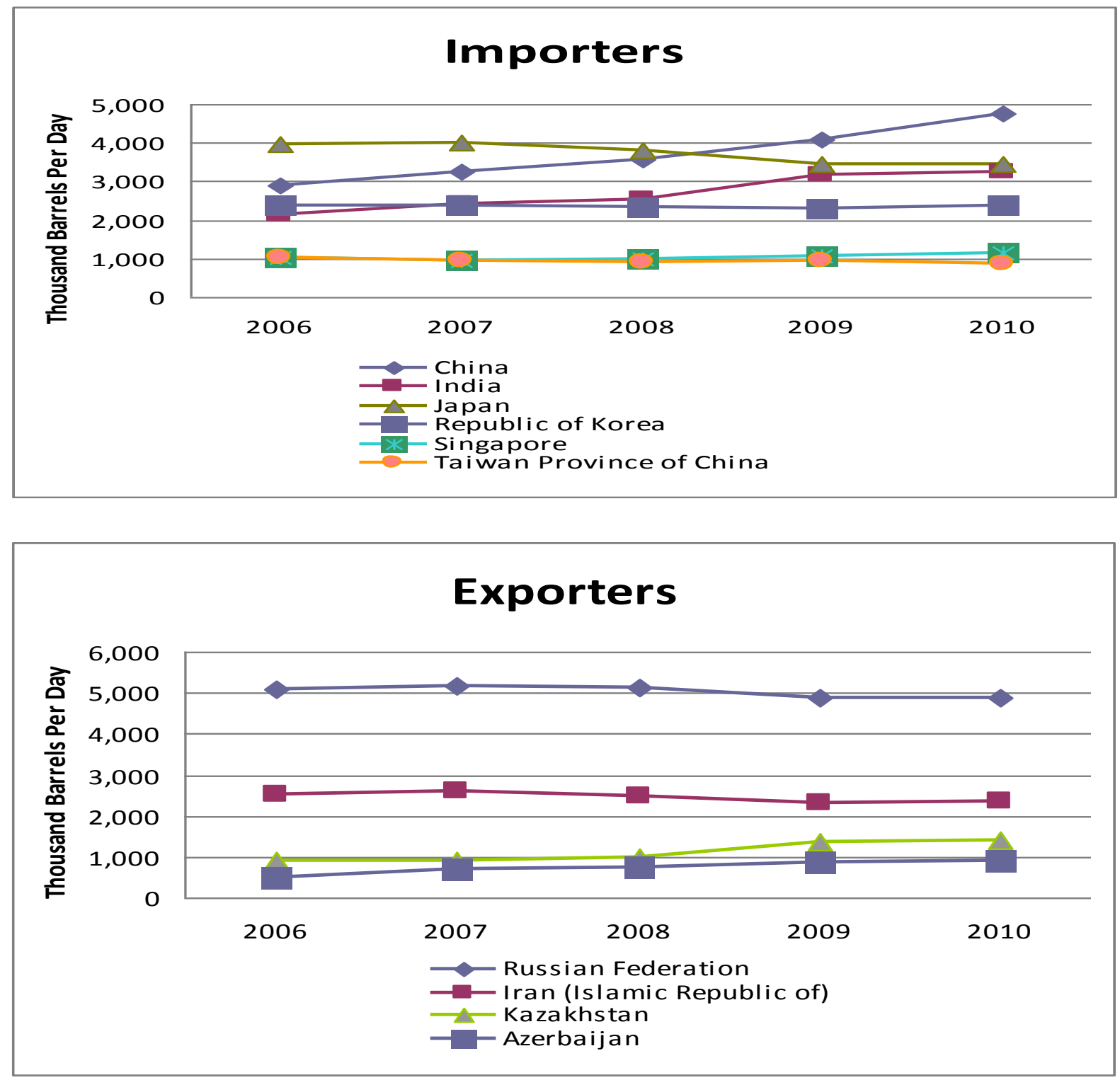

Source: Authors' calculation, based on EIA International Energy Statistics (accessed November 2013).

The Middle East was still the single largest source of Asia-Pacific oil imports, both crude and petroleum, supplying more than 54\% of the region's total oil imports in 2012. Intraregional oil trade within the Asia-Pacific region contributes $19 \%$ of the region's total oil imports. The largest exporters from the region are the Russian Federation, the Islamic Republic of Iran, Kazakhstan, and Azerbaijan. In addition, Australia, China, India, Japan, and Singapore also trade oil (mostly refined oil products) in smaller quantities and export most of it within the region. 
Figure 4: Sources of Asia-Pacific oil imports, 2008 and 2012

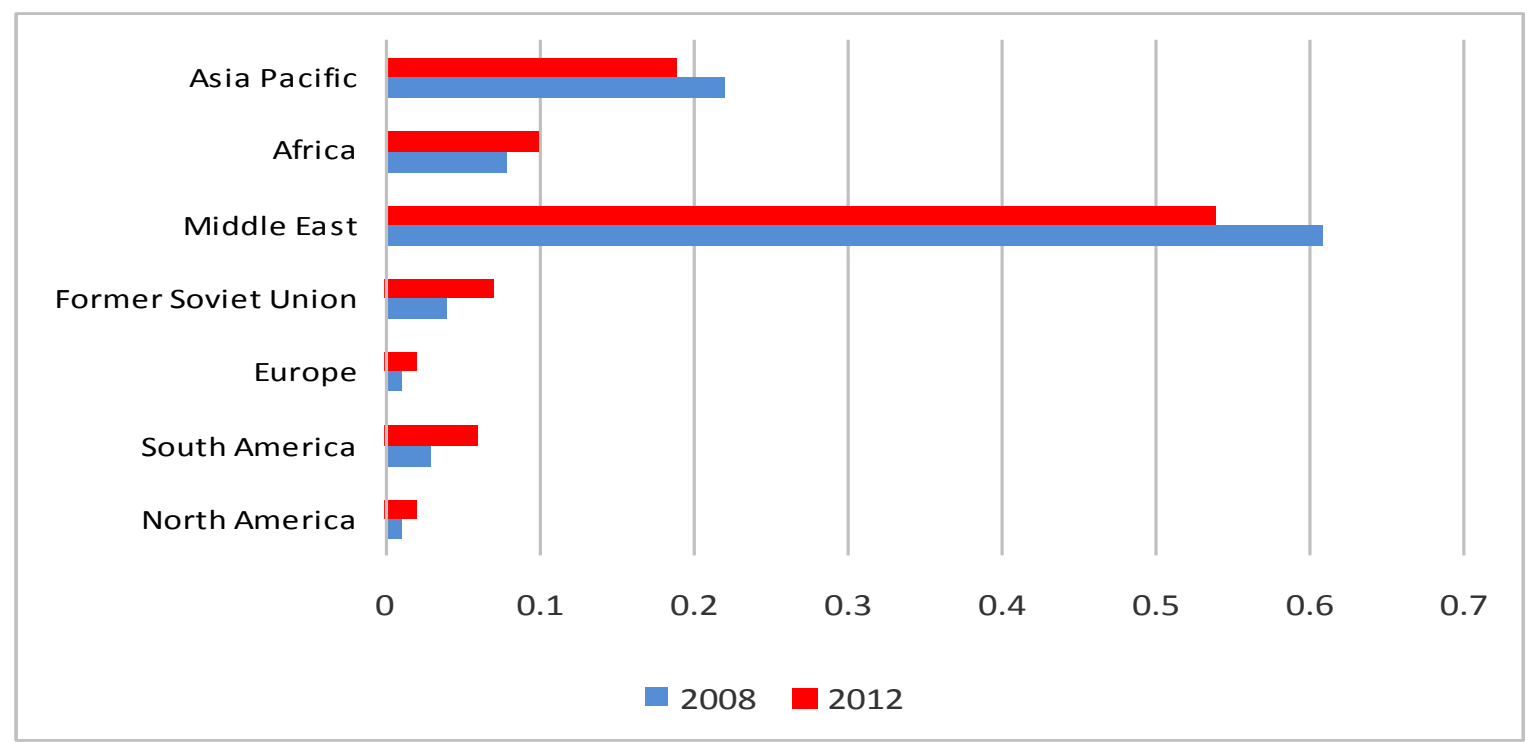

Source: Authors' calculation, based on BP Statistical Review of World Energy2009 and 2013.

Oil exports of the North Asia, Central Asia and the Russian Federation ${ }^{6}$ represented $15 \%$ of the world's total oil exports and 7\% of the Asia-Pacific region's total in 2012.

From 2008 to 2012, limited import diversification occurred, with the Middle East and intraAsia and Pacific remaining the largest sources of ESCAP oil imports, although imports from both regions decreased by 7 percentage points and 3 percentage points, respectively, over that period. The decrease in imports from "traditional suppliers" was offset by an increase in imports from Africa, South America and North, Central Asia and the Russian Federation by 8 percentage points altogether.

\subsection{Natural gas trade}

Natural gas is mostly used in the industrial and electricity-generating sectors to produce heat. It is typically seen as secondary to oil as it is less concentrated. Some 1,100 cubic metres of "gaseous" natural gas are needed to obtain one metric ton of oil equivalent (TOE) (Favennec, 2011). However, with rising climate change concerns, gas, which is seen as the "cleaner" fossil fuel, has come to the forefront of global energy demand. There are three main markets for gas - the United States of America, Europe and Asia.

${ }^{6}$ The classification of North, Central Asia and the Russian Federation has been done by the authors and this refers to the following countries: Armenia; Azerbaijan; Belarus; Georgia; Kazakhstan; Kyrgyzstan; Russian Federation; Tajikistan; Turkmenistan; Ukraine; and Uzbekistan. 
Transportation costs account for a large share of gas prices because transportation only occurs either through a pipeline, or by liquefied natural gas (LNG) carriers-mainly ships, which require a non-interruptible and rigid chain for handling. As a result, trade takes place only through those two modes. Trade by pipeline accounted for $68 \%$ of the total trade in 2012. ADB estimates that demand for natural gas will grow by $3.9 \%$ per year, reaching 1,463.2 Mtoe in 2035 (ADB, 2013). Furthermore, this projected growth will be the most rapid among all fossil fuels because of gas' lower environmental burden and ease of use.

The Asia-Pacific market for natural gas is not homogenous, owing to the lack of a wellconnected sophisticated pipeline system, such as what has been developed in North America and Europe. Regional connectivity is thus very important for Asia and the Pacific, at least for select subregions. The Asia-Pacific market can be split into three major markets North-East Asia, namely Japan, the Republic of Korea, and Taiwan Province of China, emerging markets, such as China and India; and South-East Asia, which is home to the majority of the region's LNG producers, namely Brunei Darussalam, Indonesia and Malaysia.

The Asia-Pacific region is the foremost player in LNG trade as a net importer. It imported 235 billion cubic metres (bcm) of LNG in 2012, accounting for $71 \%$ of global LNG imports. In 2012, ESCAP members and associate members imported (or $234.9 \mathrm{bcm}$ ) more than twice as much LNG as it exported (or $108.8 \mathrm{bcm}$ ). Japan alone imported $51 \%$ of the total Asian LNG imports, representing $36 \%$ of the world's total, largely due to resurgent demand following the Fukushima incident. Turkey, China, the Republic of Korea, Taiwan Province of China, Thailand, and India have been the other major LNG importers in Asia (BP 2013).

The single largest exporter of LNG to the Asia-Pacific region is Qatar, which supplied $67.7 \mathrm{bcm}$, or $29 \%$ of the region's LNG import demand, in 2012. It is also the leading LNG exporter globally. Other Middle Eastern countries that exported large quantities of LNG to Asia were Oman, Yemen, and the United Arab Emirates also registered large quantities of LNG exports to Asia. In total, the economies in the Middle East exported about $92.3 \mathrm{bcm}$ of LNG to Asia and the Pacific, roughly equivalent to $39 \%$ of the region's imports. The African countries of Algeria, Egypt, Equatorial Guinea, and Nigeria also shipped LNG to the region, totalling $28.3 \mathrm{bcm}$ or $12 \%$ of the total in shipments to Asia-Pacific. However, in aggregate, most LNG imports of Asia come from within the region, including the Russian Federation, Australia, Brunei Darussalam, Indonesia, and Malaysia, which together, supplied $46 \%$ of the region's total LNG imports in 2012. These five countries, which account for $33 \%$ of global LNG trade, are the only LNG-exporting countries from the region that essentially trade only within the region. 
Figure 5: Liquefied natural gas imports of select Asia-Pacific economies, 2012 (in billion cubic metres)

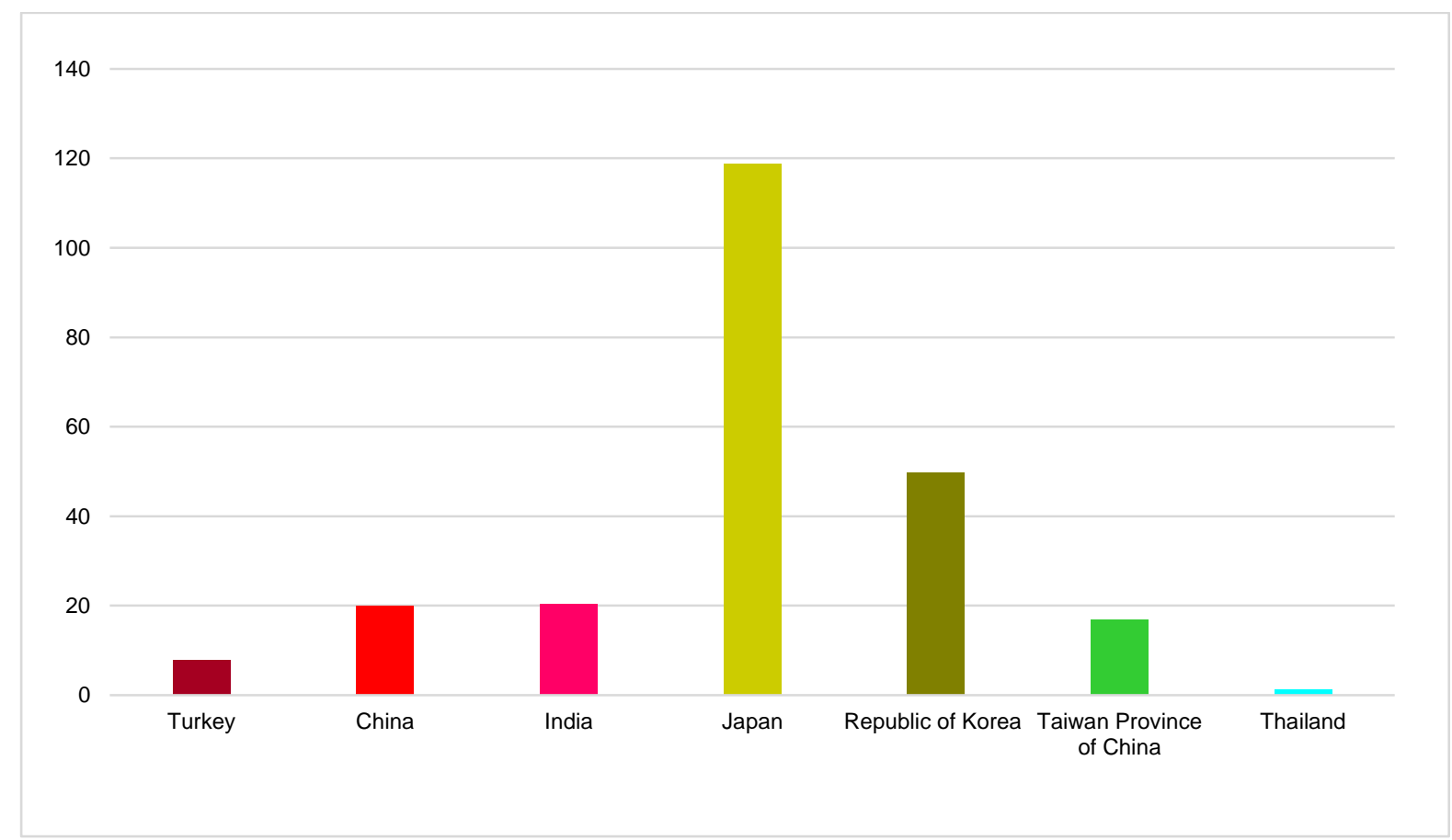

Source: Authors' calculation, based on BP Statistical Review of World Energy, 2013.

Figure 6: Liquefied natural gas exports of select Asia-Pacific economies, 2012 (in billion cubic metres)

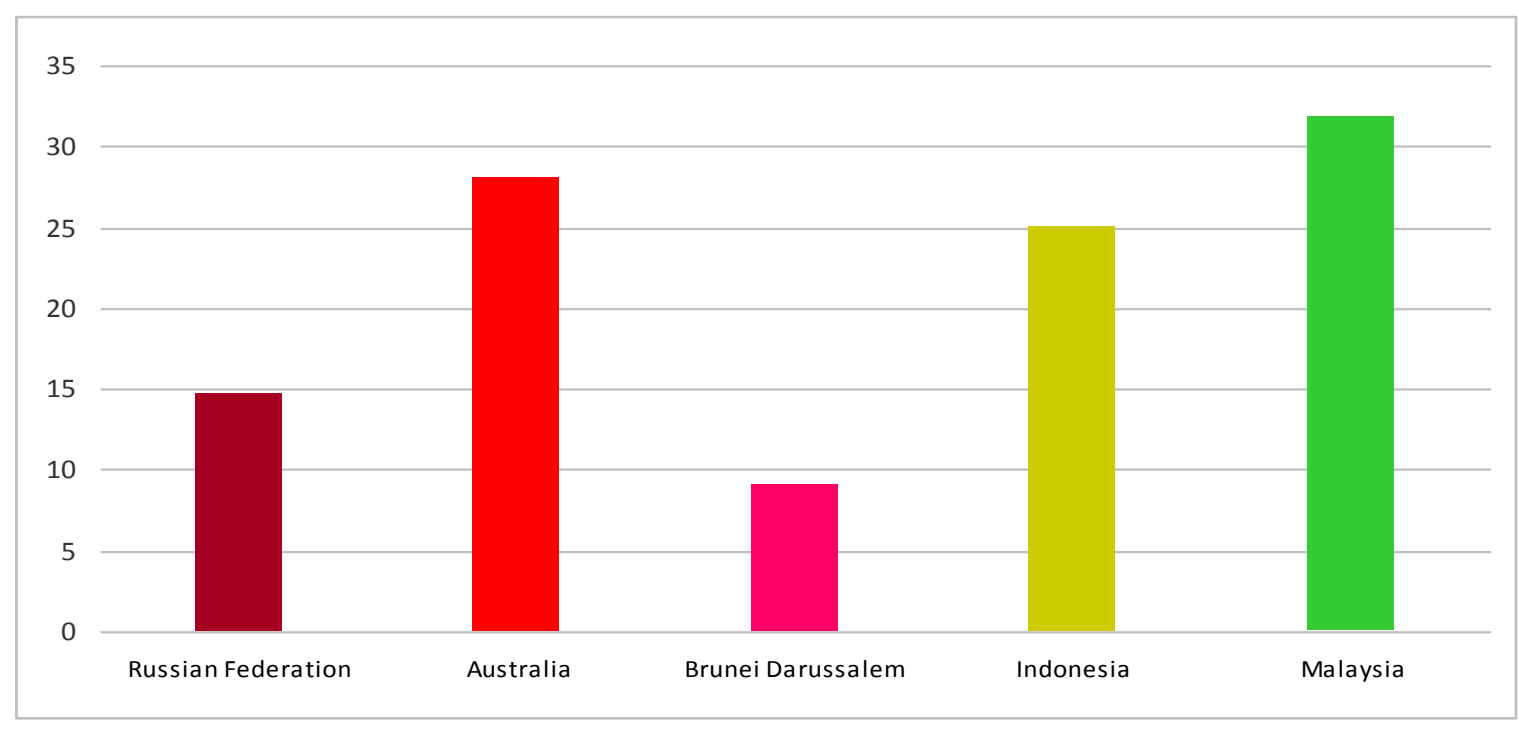

Source: Authors' calculation, based on BP Statistical Review of World Energy, 2013.

Figure 7: Natural gas imports and exports by pipeline of select Asia-Pacific economies, 2012 (in billion cubic metres) 


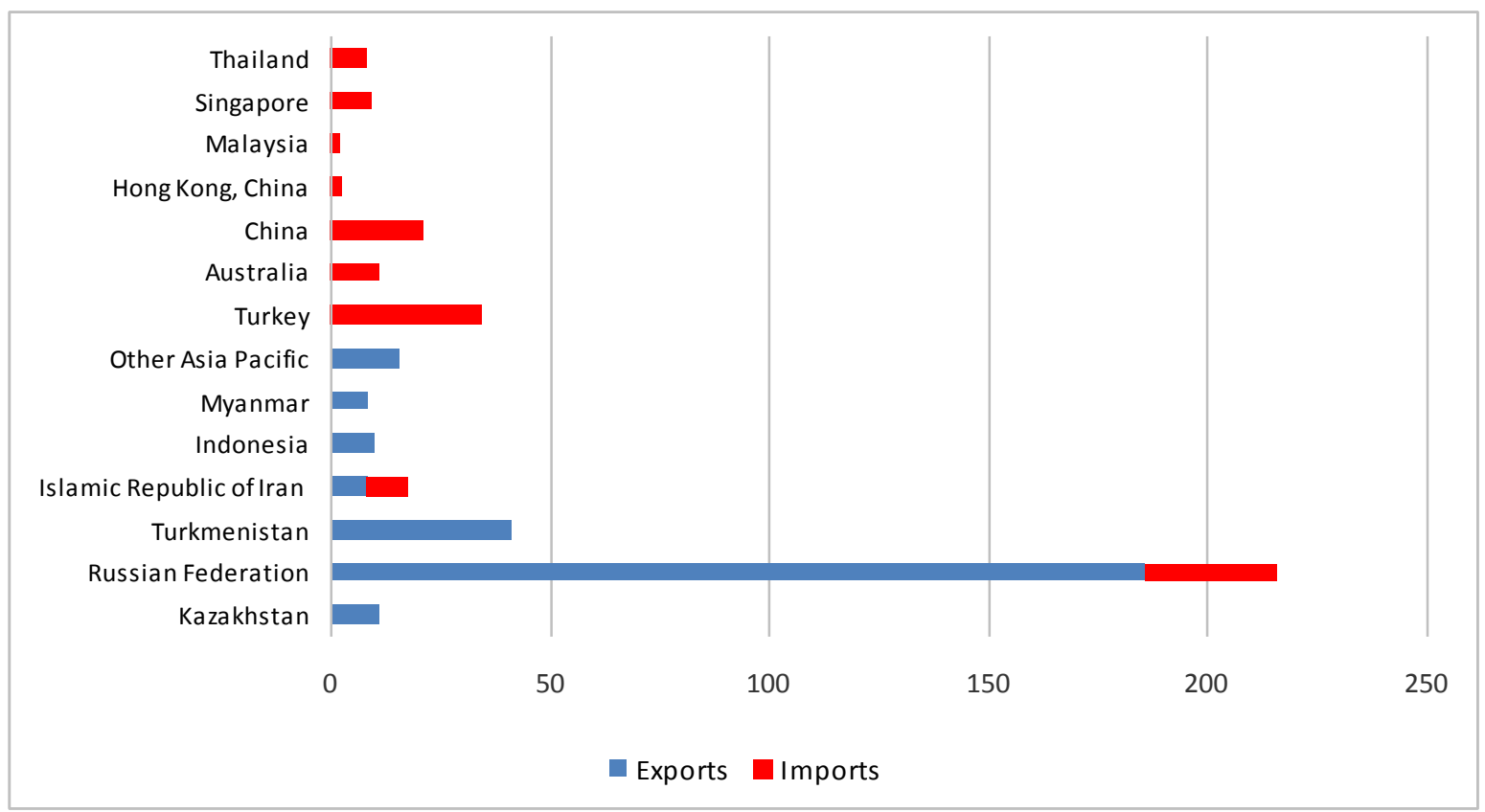

Source: Authors' calculation, based on BP Statistical Review of World Energy, 2013.

The major Asian countries that export gas by pipeline are Kazakhstan, the Russian Federation, Turkmenistan, the Islamic Republic of Iran, Indonesia and Myanmar. Other than the Russian Federation, those economies export natural gas to a small number of importers, as they each have a relatively small natural gas surplus: the Islamic Republic of Iran mainly exports to Turkey; Myanmar only to Thailand; and Indonesia only to Singapore and Malaysia. Transporting gas through pipelines is geographically constrained, as seen in the concentration of intra-South-East Asian flows, as well as in the flows among the Russian Federation and Central Asian states. One exception to this is gas exports from Turkmenistan to China, valued at $21.3 \mathrm{bcm}$. This is largely facilitated by the new Central Asian Pipelines connecting Turkmenistan, Uzbekistan, and Kazakhstan, with China. In addition to China, other Asian countries that import piped gas are Australia, Malaysia, Singapore, and Thailand. With the inclusion of the Russian Federation, the Islamic Republic of Iran and Central Asia, the Asia-Pacific region is a net exporter of natural gas as far as natural gas trade by pipeline is concerned, with exports mainly heading to Europe.

\subsection{Natural gas prices}

In addition to gas supply, gas prices are also a major concern, which needs to be addressed when considering energy security. The prices of gas in the Asia-Pacific region almost doubled between 2009 and 2012. Unlike oil and coal prices, which are largely consistent with the global price, gas prices in Asia are the Pacific are considerably higher compared to world prices. Asian gas contracts are typically indexed to crude-oil prices with maturity terms 
as long as 20 years. Thus, not only are the region's gas prices vulnerable to oil price volatility, but they are also almost quadruple the prices in the United States (figure 8).

Figure 8: Natural gas prices, 2013

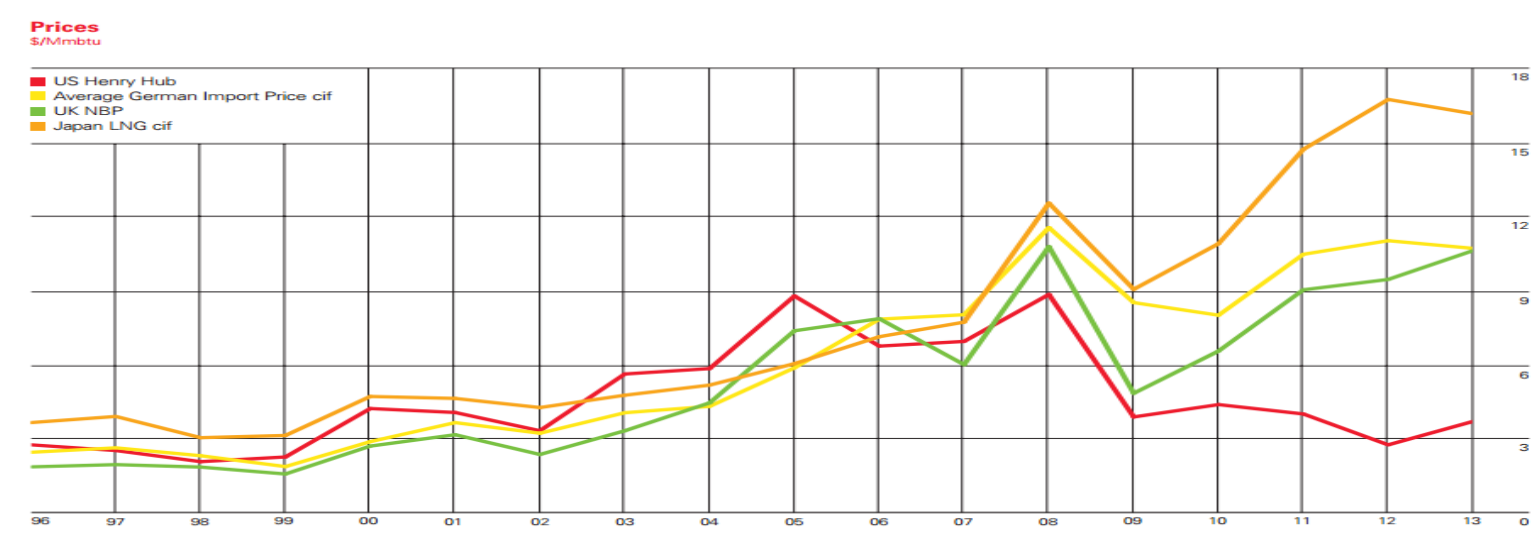

Source: BP Statistical Review of World Energy June 2014,http:/www.bp.com/content/dam/bp/pdf/Energyeconomics/statistical-review-2014/BP-statistical-review-of-world-energy-2014-natural-gas-section.pdf(accessed on November, 2013).

An ideal situation would be to delink gas prices from oil and move towards gas-to-gas competition. This is seen as a natural trajectory for the Asian gas market to follow. Such a scenario would be further boosted if surplus gas from North America were exported. Using crude oil as a benchmark for gas prices in Asia is not a credible long-term situation as oil prices are frequently distorted by the paper market, making them unrepresentative of market fundamentals. As gas is no longer seen as a direct substitute for oil in power generation, the linking of gas to oil prices is no longer relevant. Artificially maintained high gas prices in Asia negatively affect competitiveness and limit the potential for the market share of gas in the energy mix to increase. This explains why coal is still the dominant energy resource in Asia.

\subsection{Coal trade}

ADB (2013) projects that the region will become a net coal importer in 2015 while statistics from the EIA suggest that Asia and the Pacific have already become a net coal importer. Total coal exports from the Asia-Pacific region reached 920 million short tons in 2011, while coal imports amounted to 791 million short tons. Without the Russian Federation and Central Asia, the region was a net coal importer, with a trade deficit of 17 million short tons. Total Asia-Pacific coal exports also represented $72 \%$ of the global coal trade, while the imports accounted for $67 \%$ of world imports. The region's coal imports grew almost three times as fast as the global growth between 2007 and 2011, with coal imports increasing at a more rapid rate of $36 \%$ than its exports, which increased by $23 \%$. 
This phenomenon was largely fueled by burgeoning Chinese domestic demand where coal accounted for roughly $70 \%$ of total energy use in 2011. Imports to China have ballooned $349 \%$ from 2007 to2011alongside dwindling exports.

Figure 9: Global and ESCAP Coal Trade, 2007-2011 (in million short tons)

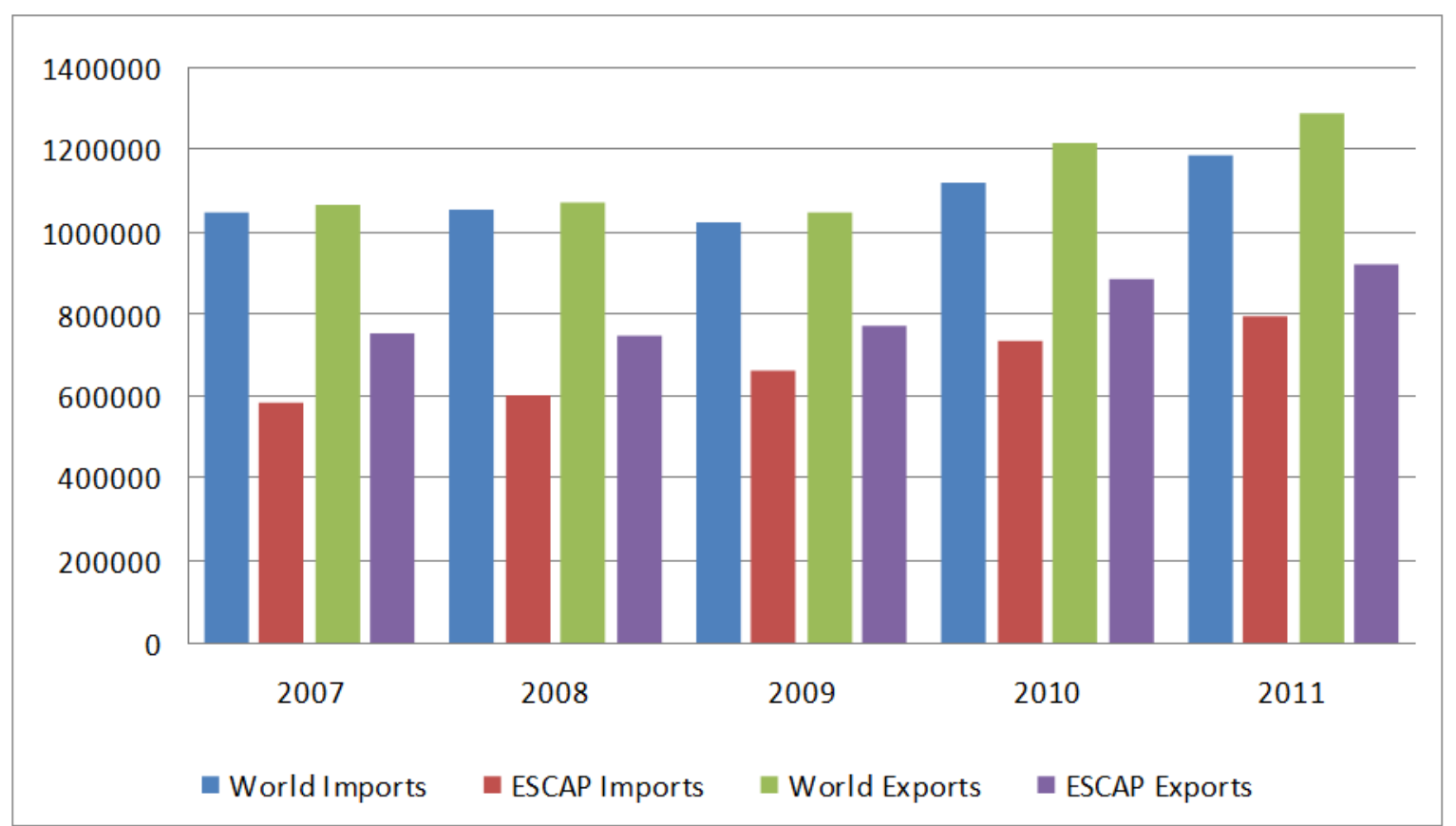

Source: Authors' calculation, based on EIA International Energy Statistics database (accessed November 2013).

The Russian Federation, Australia, and Indonesia are the region's largest coal exporters. Their combined coal exports of 793 million short tons in 2011 represented $62 \%$ and $86 \%$ of the world and region's total exports, respectively. Coal exports from those three countries increased by $33 \%$ from 2007 to 2011 , owing largely to the high growth of coal exports from Indonesia (59\% from 2007 to 2011). Indonesia has also emerged as the largest coal exporter in the region (see figure10).

China, India, Japan and the Republic of Korea are also major coal importers from the region. Together, they accounted for $58 \%$ of the world's total coal imports in 2011 and $87 \%$ of the region's total imports.

Figure 10: Growth of coal exports in key Asia-Pacific economies, 2007-2011 (in thousand short tons) 


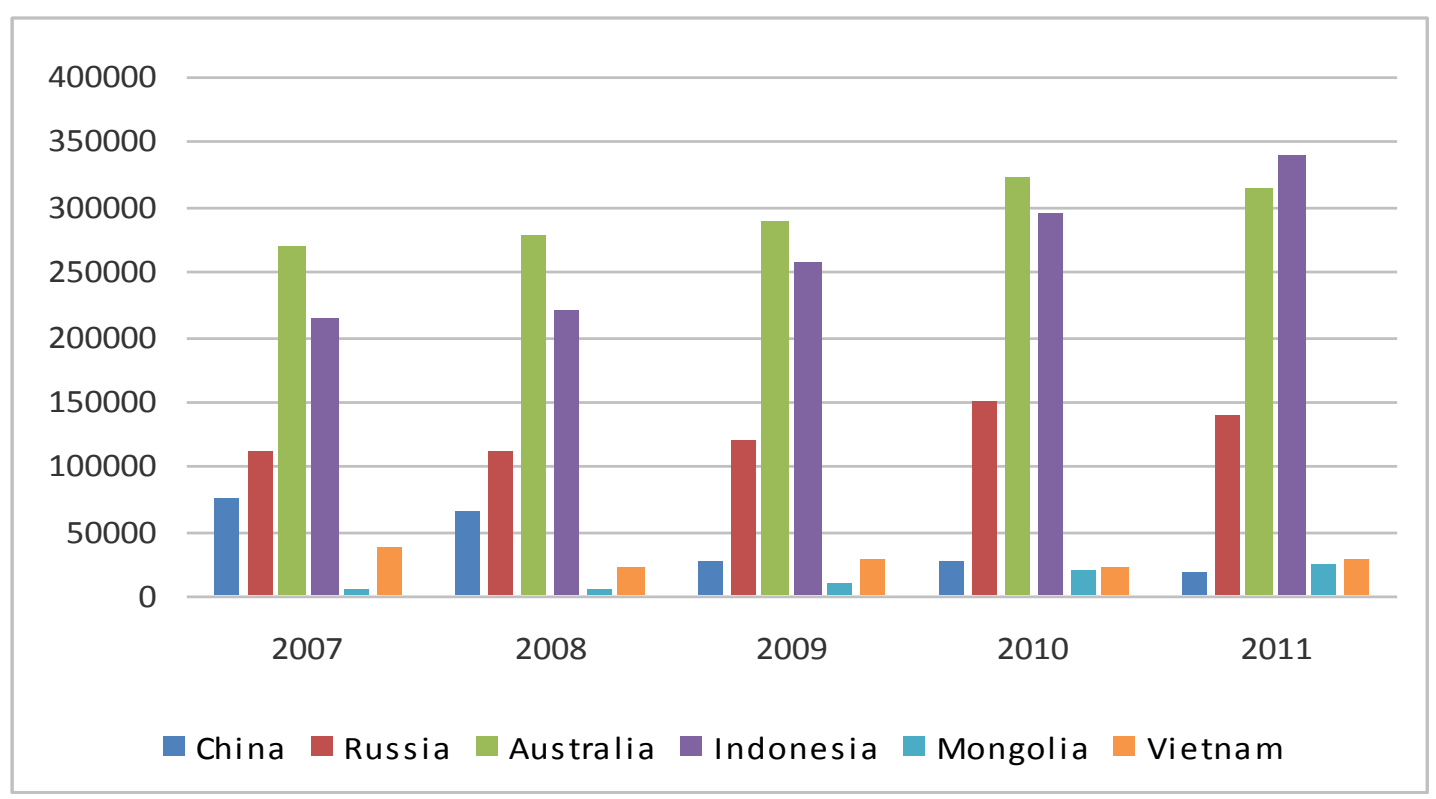

Source: Author's calculation, based on EIA, International Energy Statistics database (accessed November 2013).

China is expected to continue to be a user of coal in Asia, but based on projections of ADB, growth in demand from the country will slow to $1.4 \%$ per year through 2035 as a result of energy efficiency and an increase of other sources in the country's energy mix. Demand for coal in India, on the other hand, will increase steadily, at 3.1\% per year until 2035. At the same time, South-East Asia is poised to play a bigger role in the coal trade as certain countries in the region begin to encourage the use of coal to augment energy security, especially Indonesia, which is set to become the fourth largest coal user in Asia and the Pacific by 2035. This means that it could soon follow the path of China and see a marked erosion of its net coal exports.

\subsection{Cross-border electricity trade}

The Asia-Pacific region registered net exports of 14.77 terawatt-hours (TWh) in 2010, making it a net exporter; this was mainly driven by the export of electricity from North and Central Asia. The region's electricity exports represented $14 \%$ of the world's total electricity exports, while its electricity imports share was $11 \%$. Notably, global electricity imports decreased by $4 \%$ from 2008 to2010 while imports from the Asia-Pacific region increased by $10 \%$ during the same period. Similarly, exports decreased by $5 \%$, while exports to Asia and the Pacific increased by $2 \%$. This shows that intra-Asia-Pacific electricity trade is increasing, which is a positive development in terms of regional integration.

Figure 11: Global and Asia-Pacific electricity trade, 2008-2010( in billion Kilowatt/hour) 


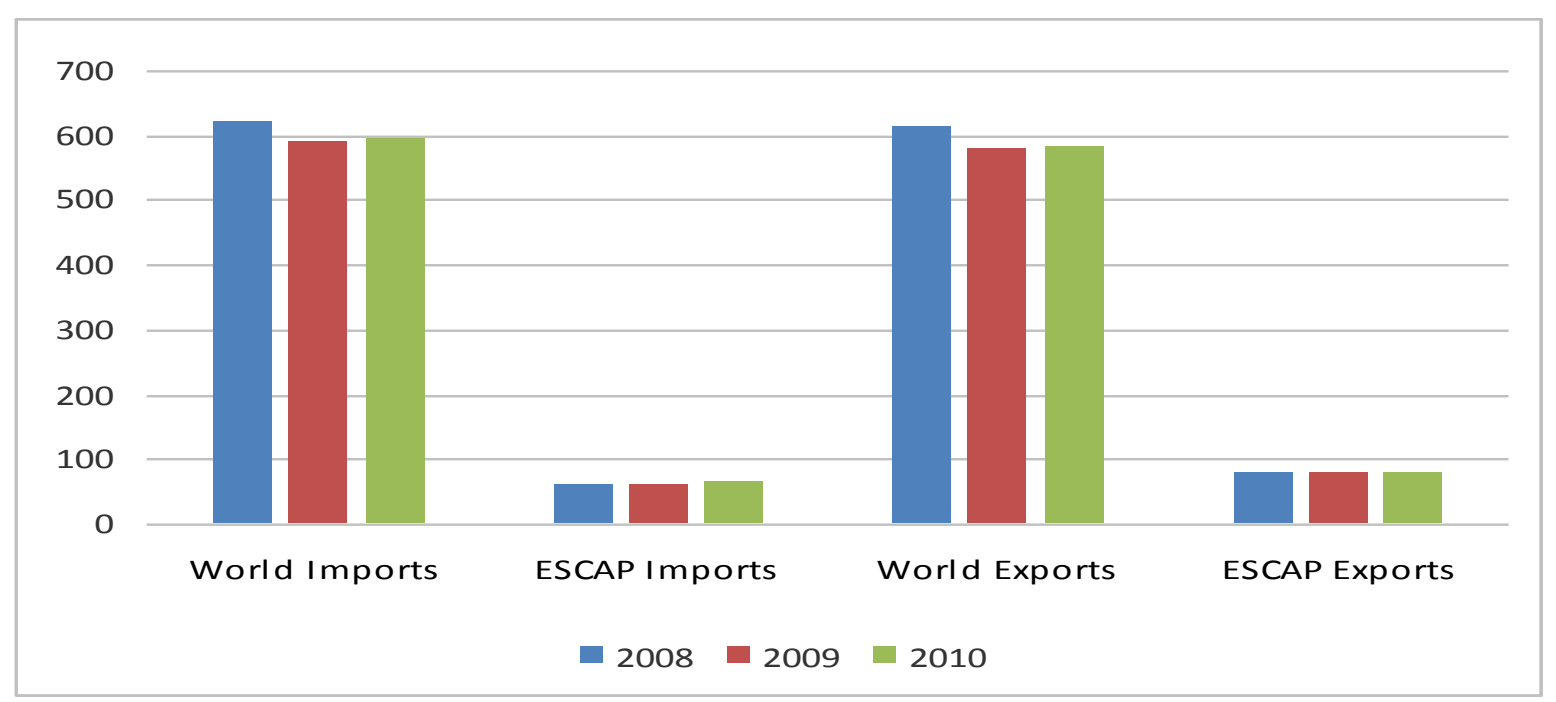

Source: Authors' calculation, based on EIA International Energy Statistics database (accessed November 2013).

Figure 12: Electricity trade of key Asia-Pacific economies, 2010 (in billion Kilowatt/hour)

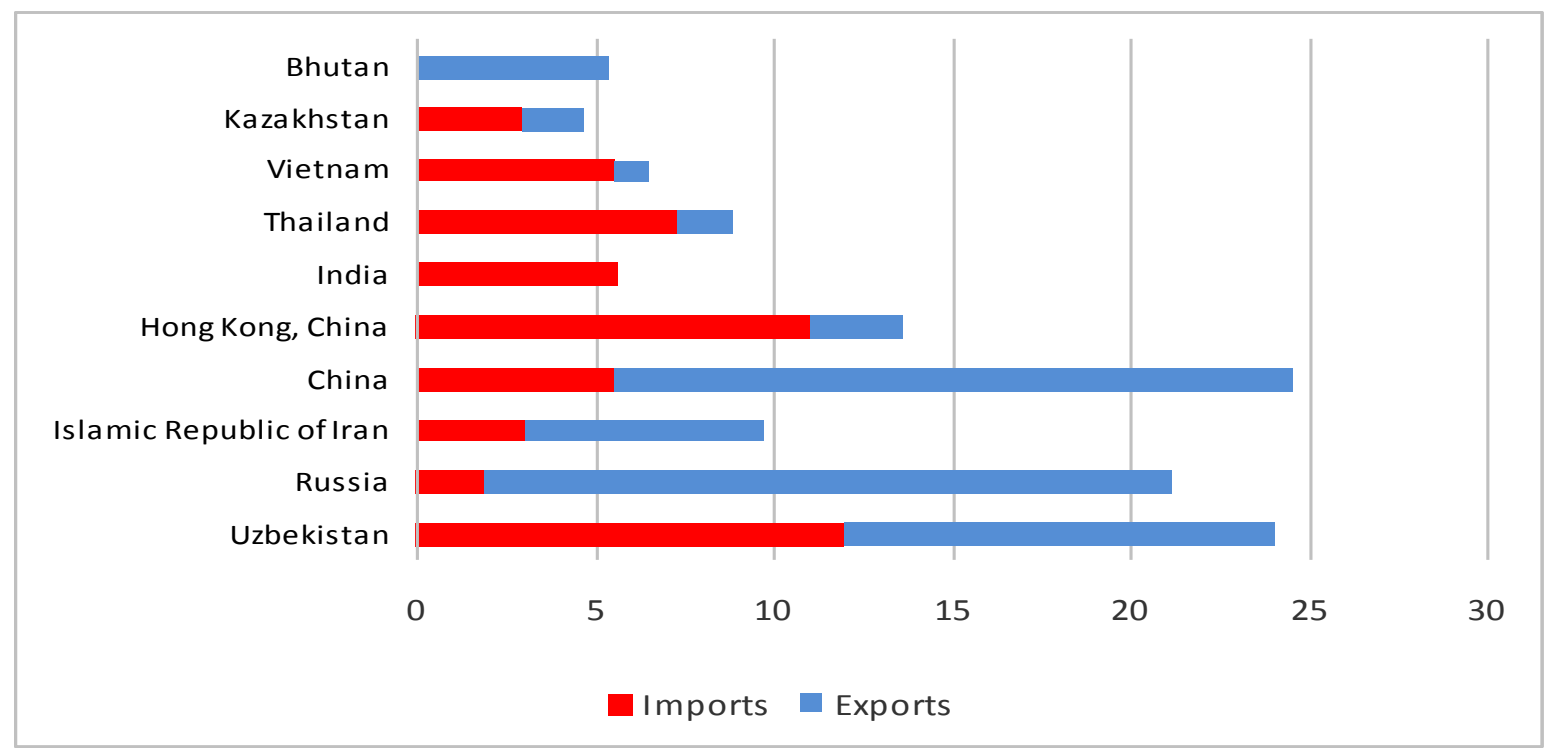

Source: Authors' calculation, based on EIA International Energy Statistics database (accessed November 2013).

The Russian Federation, Uzbekistan, the Islamic Republic of Iran, China, and Bhutan are key electricity-exporting economies, while Thailand, Uzbekistan, Hong Kong, China, India, Viet Nam, China, and Kazakhstan are key electricity-importing economies. Most of the trade, due its nature of supply, was concentrated among neighbouring countries.

Interestingly, Uzbekistan imported more or less the same amount of electricity that it exported, which represented roughly $18 \%$ of the Asia-Pacific region's imports and $15 \%$ of its exports. Electricity exports from China and the Russian Federation each made up $24 \%$ of 
the region's exports. As shown in the diagrams, both countries' imports were much less than their exports. A further $8 \%$ of ESCAP electricity exports came from the Islamic Republic of Iran. The majority of electricity exports from Bhutan are sent to India, which is its largest trade partner. Bilateral power trade has been driven by the 2006 Agreement on Trade, Commerce, and Transit between the two countries, coupled with continued growth in hydropower projects in Bhutan that is often supported by India.

While Hong Kong, China imports of electricity are high in absolute terms, representing $17 \%$ of the region's total imports and roughly equivalent to the imports of China and India combined, its case is unique given that its entire trade is conducted with China.

Figure 13: Cross-border electricity trade in the Asia-Pacific region during 2008-2010 (in billion kilowatt/hours)

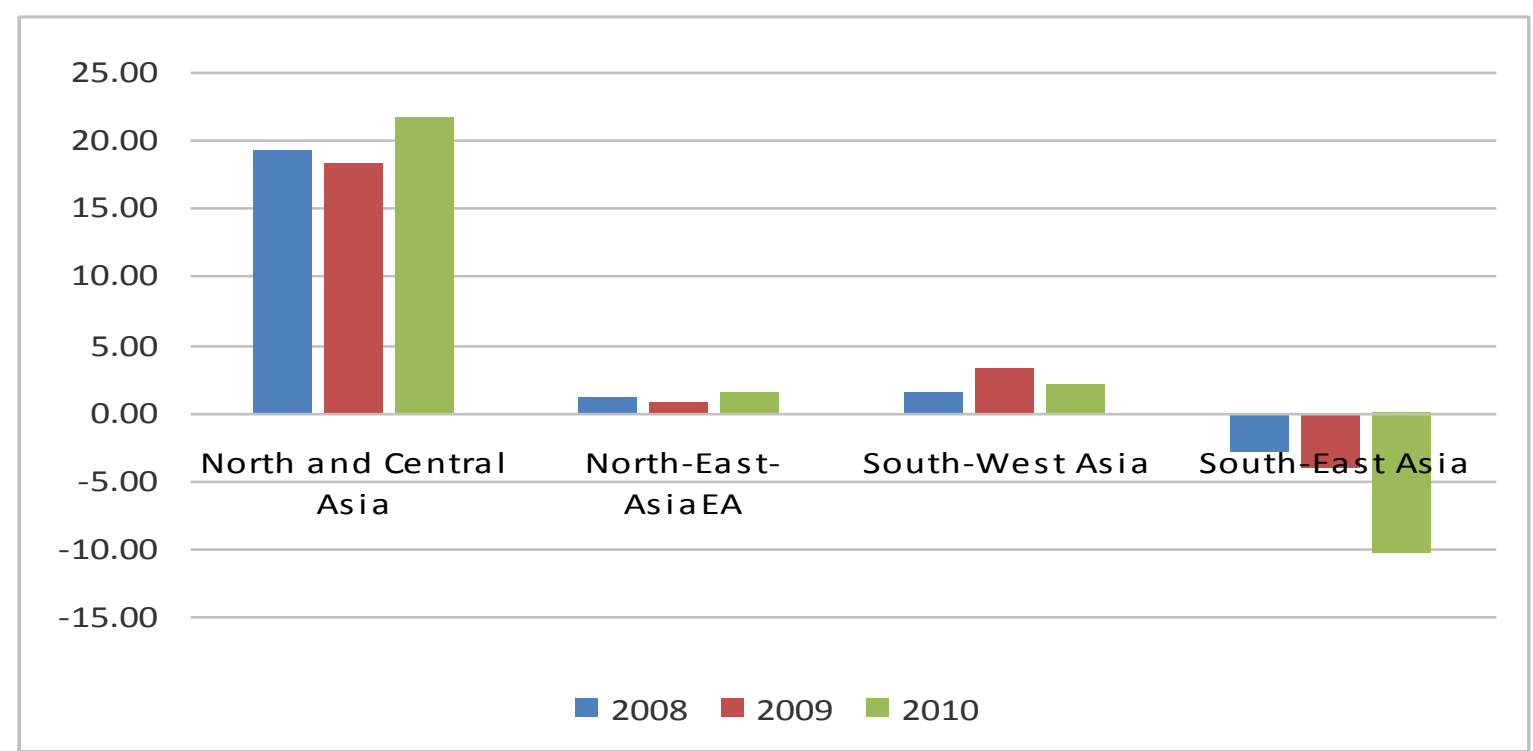

Source: Authors' calculation, based on EIA International Energy Statistics database (accessed November 2013).

Unlike trade in primary energy commodities, electricity trade can happen only within welldefined sub-regional markets, due to the specific transmission and distribution requirements. The bulk of electricity trade in Asia and the Pacific is currently taking place in North and Central Asia, which accounted for 39\% of the total electricity trade in the region in 2010 . Substantial electricity trade also occurs in East and North-East Asia, which accounted for close to $29 \%$ of the region's total in 2010 . Similarly, significant volumes of electricity trade also transpired in South-West Asia and South-East Asia.

The nature of trade is such that it requires adequate infrastructure and a distribution network at and behind the borders. In view of the fact that electricity cannot be stored, most of the countries have tried to bring predictability on supply through State-led buy-back agreements, 
which are bilateral in nature. Also, the generation of electricity through joint projects (especially for hydropower) has enhanced those bilateral flows. However, at a sub-regional or regional level much still needs to be done to facilitate the dialogue for a regional agreement.

\subsection{Summary of key energy exporting and importing countries}

Table 1: Top primary (non-renewable) and secondary energy exporters and importers in Asia and the Pacific

\begin{tabular}{|c|c|c|c|c|c|c|c|c|c|c|}
\hline \multicolumn{3}{|c|}{ Oil } & \multicolumn{2}{|c|}{ Natural gas (pipeline) } & \multicolumn{2}{|c|}{$\begin{array}{c}\text { Liquefied natural gas } \\
\text { (LNG) }\end{array}$} & \multicolumn{2}{|c|}{ Coal } & \multicolumn{2}{|c|}{ Electricity } \\
\hline & Exporter & Importer & Exporter & Importer & Exporter & Importer & Exporter & Importer & Exporter & Importer \\
\hline 1 & $\begin{array}{c}\text { Russian } \\
\text { Federation }\end{array}$ & China & $\begin{array}{c}\text { Russian } \\
\text { Federation }\end{array}$ & Turkey & Malaysia & Japan & Indonesia & Japan & $\begin{array}{c}\text { Russian } \\
\text { Federatio } \\
\mathrm{n}\end{array}$ & $\begin{array}{c}\text { Uzbekista } \\
\mathrm{n}\end{array}$ \\
\hline 2 & $\begin{array}{c}\text { Islamic } \\
\text { Republic of } \\
\text { Iran }\end{array}$ & Japan & Turkmenistan & $\begin{array}{c}\text { Russian } \\
\text { Federation }\end{array}$ & Australia & $\begin{array}{l}\text { The } \\
\text { Republic } \\
\text { of Korea }\end{array}$ & Australia & China & China & $\begin{array}{l}\text { Hong } \\
\text { Kong, } \\
\text { China }\end{array}$ \\
\hline 3 & Kazakhstan & India & Kazakhstan & China & Indonesia & India & $\begin{array}{c}\text { Russian } \\
\text { Federatio } \\
\mathrm{n}\end{array}$ & $\begin{array}{l}\text { The } \\
\text { Republic of } \\
\text { Korea }\end{array}$ & $\begin{array}{c}\text { Uzbekista } \\
\mathrm{n}\end{array}$ & Thailand \\
\hline 4 & Azerbaijan & $\begin{array}{l}\text { The } \\
\text { Republic } \\
\text { of Korea }\end{array}$ & Indonesia & Australia & $\begin{array}{c}\text { Russian } \\
\text { Federation }\end{array}$ & China & China & India & $\begin{array}{c}\text { Islamic } \\
\text { Republic } \\
\text { of Iran }\end{array}$ & India \\
\hline 5 & Indonesia & Singapore & $\begin{array}{l}\text { The Islamic } \\
\text { Republic of } \\
\text { Iran }\end{array}$ & Singapore & $\begin{array}{c}\text { Brunei } \\
\text { Darussalam }\end{array}$ & $\begin{array}{l}\text { Taiwan } \\
\text { Province } \\
\text { of China }\end{array}$ & $\begin{array}{c}\text { Kazakhsta } \\
\text { n }\end{array}$ & $\begin{array}{c}\text { Taiwan } \\
\text { Province of } \\
\text { China }\end{array}$ & $\begin{array}{l}\text { Hong } \\
\text { Kong, } \\
\text { China }\end{array}$ & Viet Nam \\
\hline
\end{tabular}

Source: Authors' calculations, based on sections 3.3.-3.6.

As shown in table 1 above a few countries consistently make up the top fossil fuel energy exporters and importers in the Asia-Pacific region, with notable exporting countries located in Central and South Asia, and major importers being China, Japan, India and the Republic of Korea.

The values of fossil fuel energy trade are significant to the overall import and export bills of the respective countries, as well as to their gross domestic product (GDP). As shown in table 2, fossil fuel energy exports represent almost one-third of the GDP of Kazakhstan and Azerbaijan, half of the merchandise exports of the Russian Federation, and more than half of the total merchandise exports of Kazakhstan, Azerbaijan, and the Islamic Republic of Iran. On the other hand, energy imports are equivalent to almost $10 \%$ of the GDP of India, and 
more than one-third of its total merchandise imports. Even the advanced diversified EastAsian economies of Japan and the Republic of Korea spend $30 \%$ of their total merchandise imports on such energy commodities.

Table 2: Exports and imports of energy for some Asia-Pacific countries in 2012*

\begin{tabular}{|c|c|c|c|c|c|c|}
\hline & $\begin{array}{c}\text { Value of } \\
\text { exports } \\
\text { (in } \\
\text { Billions } \\
\text { USD) }\end{array}$ & $\begin{array}{c}\text { Energy } \\
\text { exports } \\
\text { as a } \% \text { of } \\
\text { GDP }\end{array}$ & $\begin{array}{c}\text { Energy } \\
\text { exports as a } \% \\
\text { of total } \\
\text { merchandise } \\
\text { exports }\end{array}$ & $\begin{array}{c}\text { Value of } \\
\text { imports (in } \\
\text { Billions } \\
\text { USD) }\end{array}$ & $\begin{array}{c}\text { Energy } \\
\text { imports as a } \\
\% \text { of GDP }\end{array}$ & $\begin{array}{c}\text { Energy imports } \\
\text { as a of total } \\
\text { merchandise } \\
\text { imports }\end{array}$ \\
\hline Azerbaijan & 20.92 & $\mathbf{3 1 . 4 1 \%}$ & $\mathbf{6 4 . 1 0 \%}$ & 0.00459 & $0.01 \%$ & $0.04 \%$ \\
\hline $\begin{array}{c}\text { Islamic Republic of } \\
\text { Iran }\end{array}$ & 89.94 & $\mathbf{1 7 . 4 9 \%}$ & $\mathbf{6 8 . 1 3} \%$ & 0.0395 & $0.01 \%$ & $0.07 \%$ \\
\hline Kazakhstan & 61.1 & $\mathbf{3 0 . 0 3 \%}$ & $\mathbf{6 6 . 2 1 \%}$ & 2.9 & $1.43 \%$ & $6.52 \%$ \\
\hline Russian Federation & 263.8 & $\mathbf{1 3 . 0 9 \%}$ & $\mathbf{4 9 . 8 4 \%}$ & 1.47 & $0.07 \%$ & $0.44 \%$ \\
\hline China & 7.08 & $0.09 \%$ & $0.35 \%$ & 266.6 & $\mathbf{3 . 2 4 \%}$ & $\mathbf{1 4 . 6 6 \%}$ \\
\hline India & 0.32 & $0.02 \%$ & $0.11 \%$ & 177.9 & $\mathbf{9 . 6 6 \%}$ & $\mathbf{3 6 . 3 3 \%}$ \\
\hline Japan & 0.15 & $0.00 \%$ & $0.02 \%$ & 270.2 & $\mathbf{4 . 5 3 \%}$ & $\mathbf{3 0 . 5 0 \%}$ \\
\hline
\end{tabular}

Note: Energy exports and imports are comprised of oil (HS 2709), gas (HS 2711), coal (2701), and electricity (HS 2716).

Source: Authors' calculations. Values of energy exports taken from United Nations COMTRADE data downloaded from WITS database (accessed December 2013). GDP values taken from World Bank Country Profiles (accessed December 2013). Values of merchandise exports and imports taken from UNCTADstat (accessed December 2013).

*All values stated are for 2012, except for those from the Islamic Republic of Iran, which are based on 2011 figures. Values for total merchandise exports and imports of the Islamic Republic of Iran in 2011 have been estimated by the United Nations Conference on Trade and Development.

As a result, key energy exporting countries are heavily reliant on their fossil fuel energy exports to fuel their economic development, while energy imports pose a considerable burden on the trade balance of major energy-importing countries.

Table 3: Top renewable energy exporters and importers in Asia-Pacific

\begin{tabular}{|c|c|c|c|c|c|}
\hline $\begin{array}{c}\text { Climate-smart goods } \\
\text { and technologies }\end{array}$ & Solar photovoltaic & Wind power & Clean coal & $\begin{array}{c}\text { Energy-efficient } \\
\text { lighting }\end{array}$ \\
\hline
\end{tabular}




\begin{tabular}{|c|c|c|c|c|c|c|c|c|c|c|}
\hline & Exporter & Importer & Exporter & Importer & Exporter & Importer & Exporter & Importer & Exporter & Importer \\
\hline 1 & China & China & China & China & Japan & China & Japan & Australia & Indonesia & China \\
\hline 2 & Japan & $\begin{array}{l}\text { The } \\
\text { Republic } \\
\text { of Korea }\end{array}$ & Japan & $\begin{array}{c}\text { The } \\
\text { Republic } \\
\text { of Korea }\end{array}$ & China & $\begin{array}{l}\text { The } \\
\text { Republic } \\
\text { of Korea }\end{array}$ & Singapore & $\begin{array}{c}\text { Russian } \\
\text { Federation }\end{array}$ & Japan & Indonesia \\
\hline 3 & $\begin{array}{l}\text { The } \\
\text { Republic } \\
\text { of Korea }\end{array}$ & Japan & $\begin{array}{l}\text { The } \\
\text { Republic } \\
\text { of Korea }\end{array}$ & $\begin{array}{l}\text { Hong } \\
\text { Kong, } \\
\text { China }\end{array}$ & $\begin{array}{l}\text { The } \\
\text { Republic } \\
\text { of Korea }\end{array}$ & Japan & $\begin{array}{c}\text { Russian } \\
\text { Federation }\end{array}$ & Japan & $\begin{array}{c}\text { Russian } \\
\text { Federation }\end{array}$ & Thailand \\
\hline 4 & Singapore & $\begin{array}{l}\text { Hong } \\
\text { Kong, } \\
\text { China }\end{array}$ & Malaysia & Japan & Singapore & Indonesia & India & Singapore & $\begin{array}{l}\text { Republic } \\
\text { of Korea }\end{array}$ & Japan \\
\hline 5 & Malaysia & $\begin{array}{c}\text { Russian } \\
\text { Federation }\end{array}$ & Singapore & Australia & India & India & Thailand & $\begin{array}{l}\text { Republic } \\
\text { of Korea }\end{array}$ & Thailand & India \\
\hline
\end{tabular}

Source: Climate-smart Trade and Investment in Asia and the Pacific, 2011.

Table 3 shows that North-East and South-East Asian countries dominate trade in renewable energy systems. Unlike trade in fossil fuel resources, the same few countries are both exporting and importing most of the low-carbon goods and technologies in the region.

It is thus clear that enough opportunity exists to trade in energy within the region. This only requires good connectivity at national and subregional levels for which investments in crossborder infrastructure will be required. At the same time, in order to achieve predictability and sustainability, legally binding commitments by all parties in energy trade and cooperation will be required.

\section{Regional trade and energy security}

In their quest for energy security, countries are engaged in agreements on energy trade. Most of these agreements are bilateral in nature. Efforts are also taken at a regional level to talk about energy cooperation and security. The regional trade agreements, now an essential part of the international trading system, are also playing an important role in facilitating energy trade for energy security. The RTAs being economic integration agreements can facilitate trade in energy either through the offer of preferential tariff concessions or can have a larger agenda on cooperation and security. In Asia-Pacific region the regional integration efforts have also led to cooperation agreements on energy. ASEAN has an agreement on Energy Cooperation (1986) to ensure and develop the sources of energy in strengthening the economic resilience of ASEAN members. SAARC also has a 
Framework Agreement for Energy Cooperation (Electricity) (2014) to enhance cooperation in the energy sector to facilitate energy trade, development of efficient conventional and renewable energy sources including hydropower. Energy is a sector for cooperation in BIMSTEC which acts a bridging link between ASEA and SAARC.

\subsection{Efforts towards energy cooperation and security}

In view of the rising energy cost burden on national income and recognition by both energyrich and energy-poor countries of the importance of sustainable development, greater efforts have been undertaken towards consolidating energy security. Such initiatives vary in terms of commitment and impact. This section covers several pertinent ones in recent years.

At the multilateral level, the Energy Charter Treaty was established in 1994 and entered into legal force in 1998. The fundamental aim of the Energy Charter Treaty is to strengthen the rule of law on energy issues by creating a level playing field of rules to be observed by all participating Governments, thereby mitigating risks associated with energy-related investment and trade (Energy Charter). Its specific focus on energy trade and investment differs from other frameworks, in which trade and investment issues are typically subsets of a broader goal. In addition, it is a legally binding multilateral instrument with a comprehensive dispute settlement process. The Treaty has been signed or acceded to by fifty-two States, the European Community and Euratom; ;it therefore has 54 members, (Energy Charter).A total of 14 ESCAP countries have full member status in the Energy Charter treaty, including all the North and Central Asian countries, Afghanistan, Australia, Japan, Mongolia, and Turkey, and another five (China, Indonesia, Islamic Republic of Iran, the Republic of Korea, and Pakistan) are observers to the treaty.

At a regional level, ESCAP member States have forged a ministerial declaration and plan of action on regional cooperation for enhanced energy security and the sustainable use of energy in Asia and the Pacific for 2014-2018. This was an outcome of the inaugural Asian and Pacific Energy Forum, which was held in Vladivostok, Russian Federation in May 2013 and is based on implementing ESCAP Commission resolution 67/2 on promoting regional cooperation for enhanced energy security and the sustainable use of energy in Asia and the Pacific, which was adopted on 25 May 2011. Energy trade and investment is one of the seven focus areas identified for regional cooperation (ESCAP, 2013a).

At the same time, another ESCAP-led initiative, termed the Asian Energy Highway has also been endorsed in 2011, under resolution 68/11 - Connectivity for Energy Security. Through

\footnotetext{
${ }^{7}$ European Atomic Energy Community
} 
the resolution, the Commission seeks to realize the development of an integrated regional power grid. Advances in energy generation and transmission technologies, such as the improvement in high-voltage transmission systems, such as high-voltage direct current (HVDC) and smart grid communication and management technologies, have made the Asian Energy Highway increasingly feasible (ESCAP, 2013a).

Energy trade has also figured prominently in numerous subregional energy initiatives. In South-East Asia, the ASEAN Power Grid project, as well as the ADB-backed interconnection projects under the Greater Mekong Subregion programme promotes electricity trade and is complementary to the Asian Energy Highway. The programme notably connects China to South-East Asia. In addition, the Association of South-East Asian Nations (ASEAN) has also initiated the Trans-ASEAN Gas Pipeline to enhance natural gas trade. Inter subregional cooperation also exists, particularly between South and Central Asia. Funded by ADB, the Turkmenistan-Afghanistan-Pakistan-India Natural Gas Pipeline Project aims to export up to 33 billion cubic meters $(\mathrm{bcm})$ of natural gas per year through a proposed 1,800-kilometer (km) pipeline spanning from Turkmenistan to Afghanistan, Pakistan and India (ADB, 2013).

Beyond traditional energy trade cooperation, extensive cooperation on trade intelligence, particularly on oil trade, has been attempted on a global level. A prominent example is the Join-Oil Data Initiative, which seeks to promote energy security through improved oil data and greater data reliability and transparency. Members of the initiative consists of six pioneer organizations: the Asia-Pacific Economic Cooperation (APEC), the Statistical Office of the European Communities (Eurostat), the International Energy Agency (IEA), the LatinAmerican Energy Organization (OLADE), the Organization of Petroleum Exporting Countries (OPEC) and the United Nations (through the Statistics Division) (JODI, 2013). More than 90 countries, representing around $90 \%$ of the global oil supply and demand participate in submitting critical energy data through the initiative (JODI, 2013).

\subsection{Energy security and trade implications for regional trade agreements - the case of the Asia-Pacific Trade Agreement}

The Asia-Pacific Trade Agreement (APTA) ${ }^{8}$ is the oldest preferential trade agreement among developing countries of the Asia-Pacific region that aims at promoting South-South regional trade through the exchange of mutually agreed concessions by member countries. The objectives of APTA, as stipulated in Article 2 of the revised text, "are to promote economic development through a continuous process of trade expansion among the developing member countries of ESCAP and to further international economic cooperation through the

${ }^{8}$ ESCAP's Trade and Investment Division functions as APTA's Secretariat. 
adoption of mutually beneficial trade liberalization measures consistent with their respective present and future development and trade needs". In order to achieve these objectives, the members exchange tariff concessions on selected goods among themselves.

This section discusses how APTA members are trading in energy and if APTA can be useful in connecting the APTA members with the other economies of Asia-Pacific in enhancing energy trade and facilitating energy security.

Efforts aimed at achieving energy security through connectivity and integration is being undertaken at various levels. Given the importance of international trade with regard to energy integration, a platform to facilitate trade in energy at a much lower cost is a requisite. Most countries, even those that are highly dependent on energy, charge import duties and other taxes on imports. This raises the cost of energy to the ultimate consumer and consequently has a spillover effect on other economic activities and development. In order to create a more efficient and cheaper energy trade system, and thus a more secure option, it is important to implement a trade agreement among the countries that are part of shared national, subregional or regional energy supply and demand connectivity. Having preferential terms of trade through some agreement would thus be important for energy security in the long term. In this regard, it is essential to examine if a framework exists in Asia and the Pacific to facilitate energy security through a trade agreement or a new initiative is required on this front. This section aims to examine this.

The Asia-Pacific Trade Agreement applies to goods traded at the regional level. It is open to developing member countries of ESCAP. Currently, there are more than $150^{\circ}$ preferential trade agreements in Asia and the Pacific. The Asia-Pacific Trade Agreement being reviewed for this report, as it is the only agreement that is region-wide and includes among its participating States the three major economies of Asia and the Pacific - China, India and the Republic of Korea, the greatest users of energy in the region. The Agreement is legally binding and tariff concessions on goods are being exchanged under it. Focusing on a subregional agreement/grouping, instead individual country-specific energy demand, can benefit not only participating States of the Agreement, but also the other countries that become a part of energy supply chain. Limited concessions on energy goods are already given under the Agreement in the fourth round of negotiations as shown in the table below.

\section{Table 4: Energy concessions given under the Asia-Pacific Trade Agreement in the fourth round negotiations}

\footnotetext{
${ }^{9}$ ESCAP's Asia Pacific Trade and Investment Database (April 2015)
} 


\begin{tabular}{|c|c|c|c|c|c|c|c|}
\hline & Bangladesh & China & India & $\begin{array}{r}\text { Lao } \\
\text { People's } \\
\text { Democratic } \\
\text { Republic }\end{array}$ & Mongolia & $\begin{array}{c}\text { The } \\
\text { Republic } \\
\text { of Korea }\end{array}$ & Sri Lanka \\
\hline Coal & No & Yes & Yes & No & No & No & Yes \\
\hline Oil & No & No & No & No & No & Yes & No \\
\hline LNG & Yes & No & No & No & Yes & No & No \\
\hline Natural Gas & No & No & No & No & No & Yes & No \\
\hline Electricity & Yes & No & No & No & No & No \\
\hline
\end{tabular}

Source: Authors' compilation on the basis of APTA concessions.

Energy security through international trade is important to the APTA members. China, India, and the Republic of Korea remain among the top importers of the three primary fossil fuels (oil, gas, and coal). Conversely, the Central and South Asian countries of the Islamic Republic of Iran, Kazakhstan, Azerbaijan, the Russian Federation, and Turkmenistan are the top fossil fuel exporters in the region. In view of this fact, the following section examines how APTA members as well as the Central and South Asian economies will benefit if they all join APTA as members and exchange preferential tariff concessions on energy.

In addition to being large exporters of fossil fuels, these Central and South Asian countries possess significant fossil fuel reserves (figure 14). As a group, the 11 countries Central and South Asia, ${ }^{10}$ possess $14 \%$ of global oil reserves, $31 \%$ of global gas reserves, and $19 \%$ of global coal reserve.

\footnotetext{
${ }^{10}$ The CSA grouping includes: Armenia; Azerbaijan; Georgia;Islamic Republic of Iran; Kazakhstan; Kyrgyzstan; Russian Federation, Tajikistan; Turkmenistan; Uzbekistan; and Turkey.
} 
Figure 14: Fossil fuel reserves of key Central and South Asian countries

\section{Oil Reserves of Key Central and South Asian Countries}

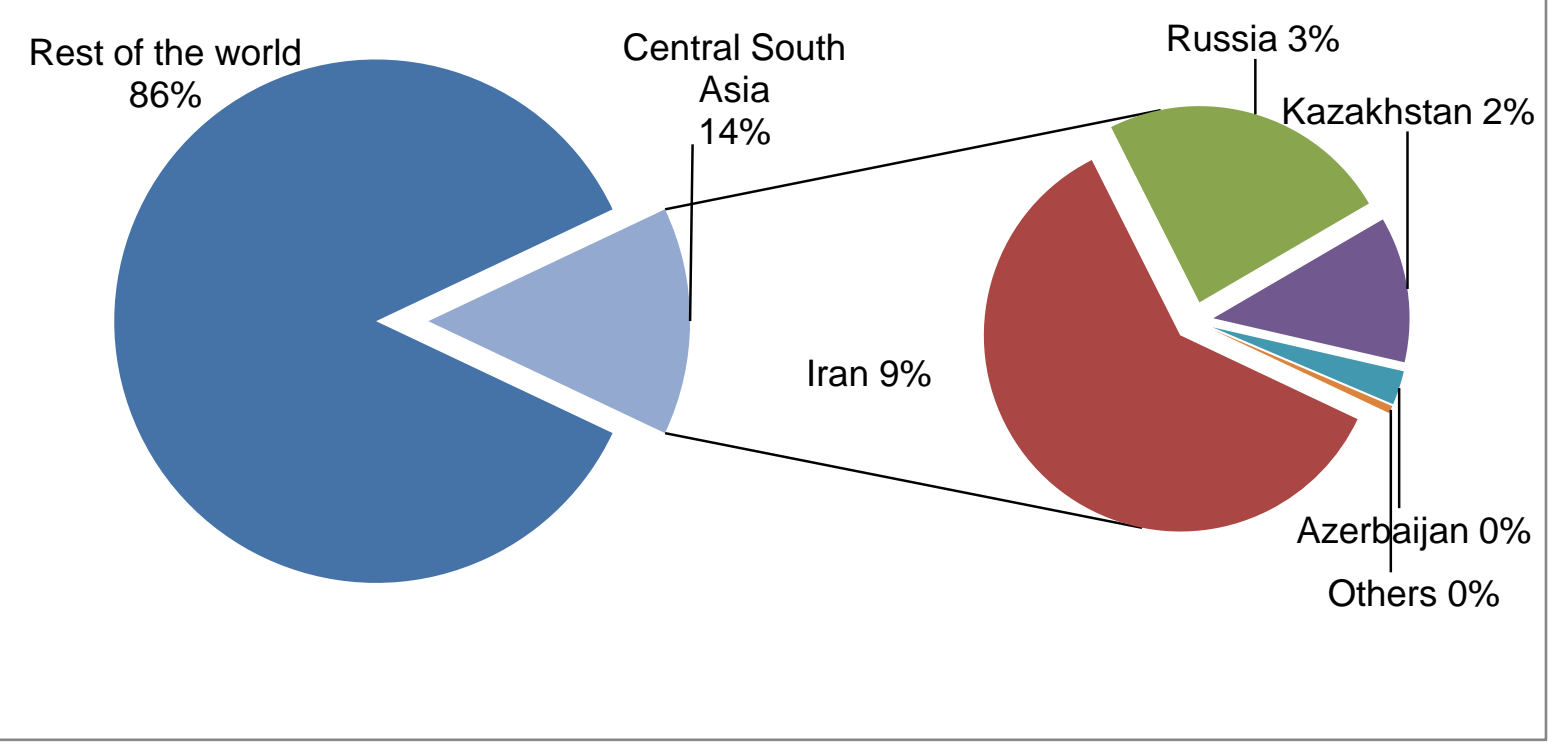

\section{Gas Reserves of Key Central and South Asian Countries}

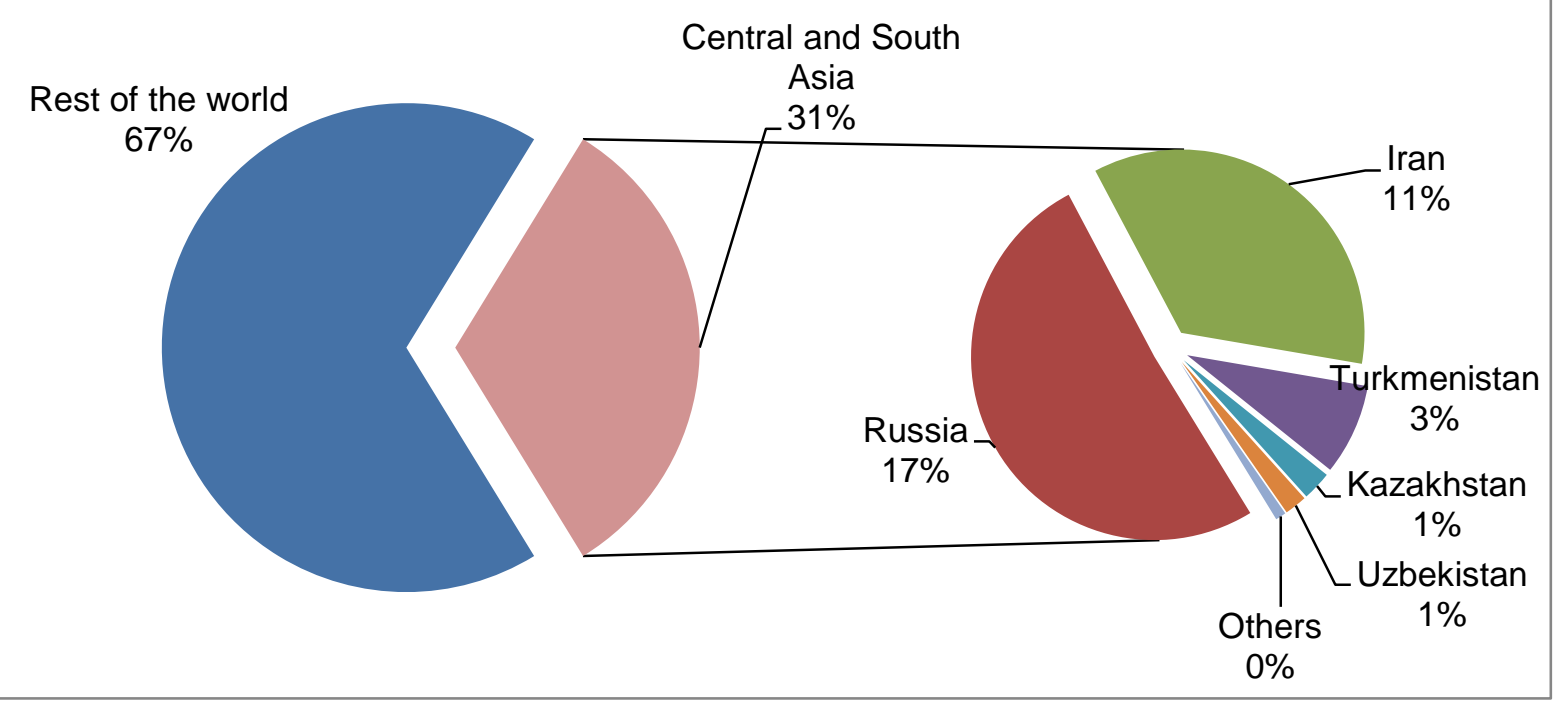




\section{Coal Reserves of Key Central and South Asian Countries}

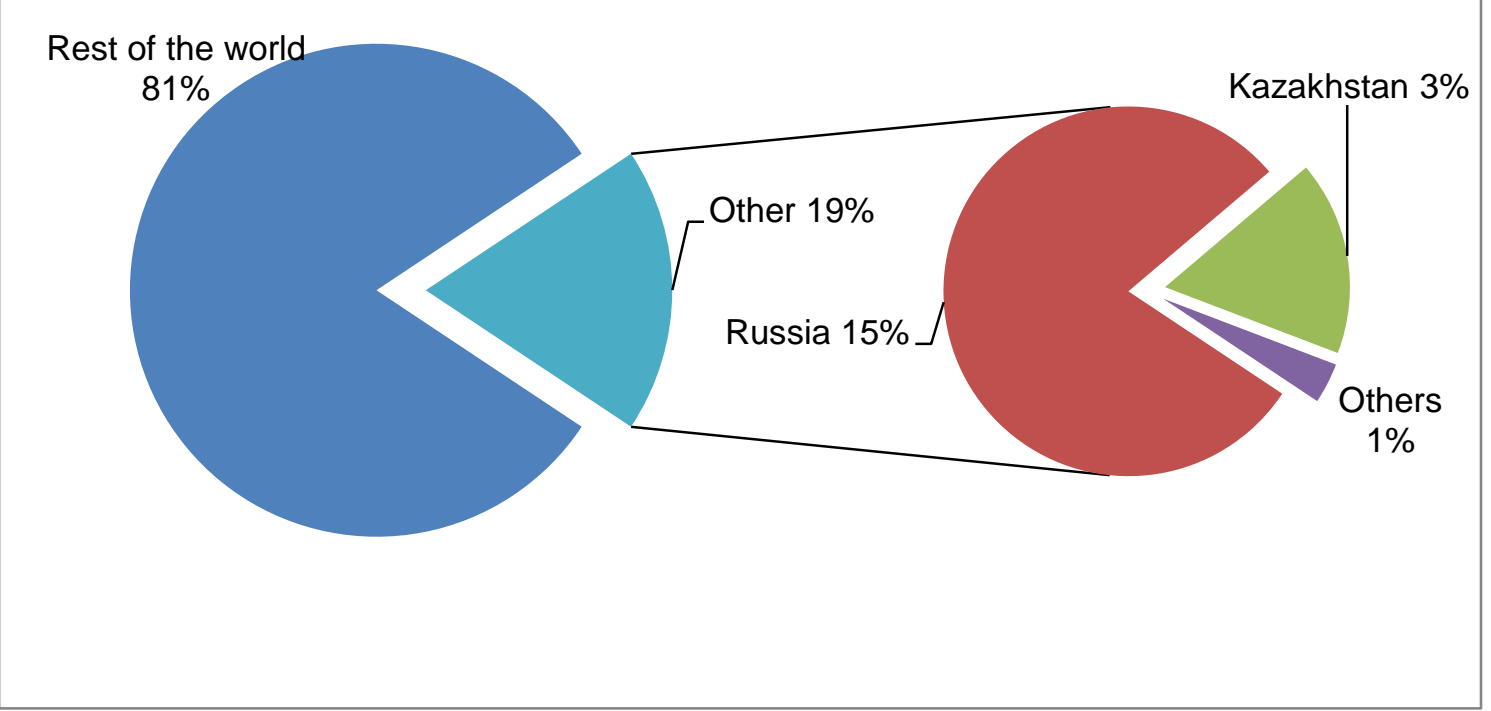

Source: Authors' calculations, based on EIA, International Energy Statistics database.

Electricity trade is also a key issue for participating members of the Asia-Pacific Trade Agreement, as six out the seven member countries ( the Republic of Korea is the exception) were among the top countries in Asia and the Pacific with the greatest number of people without access to electricity in 2012 (figure 15). 
Figure 15: People without access to electricity in the Asia-Pacific region, 2012
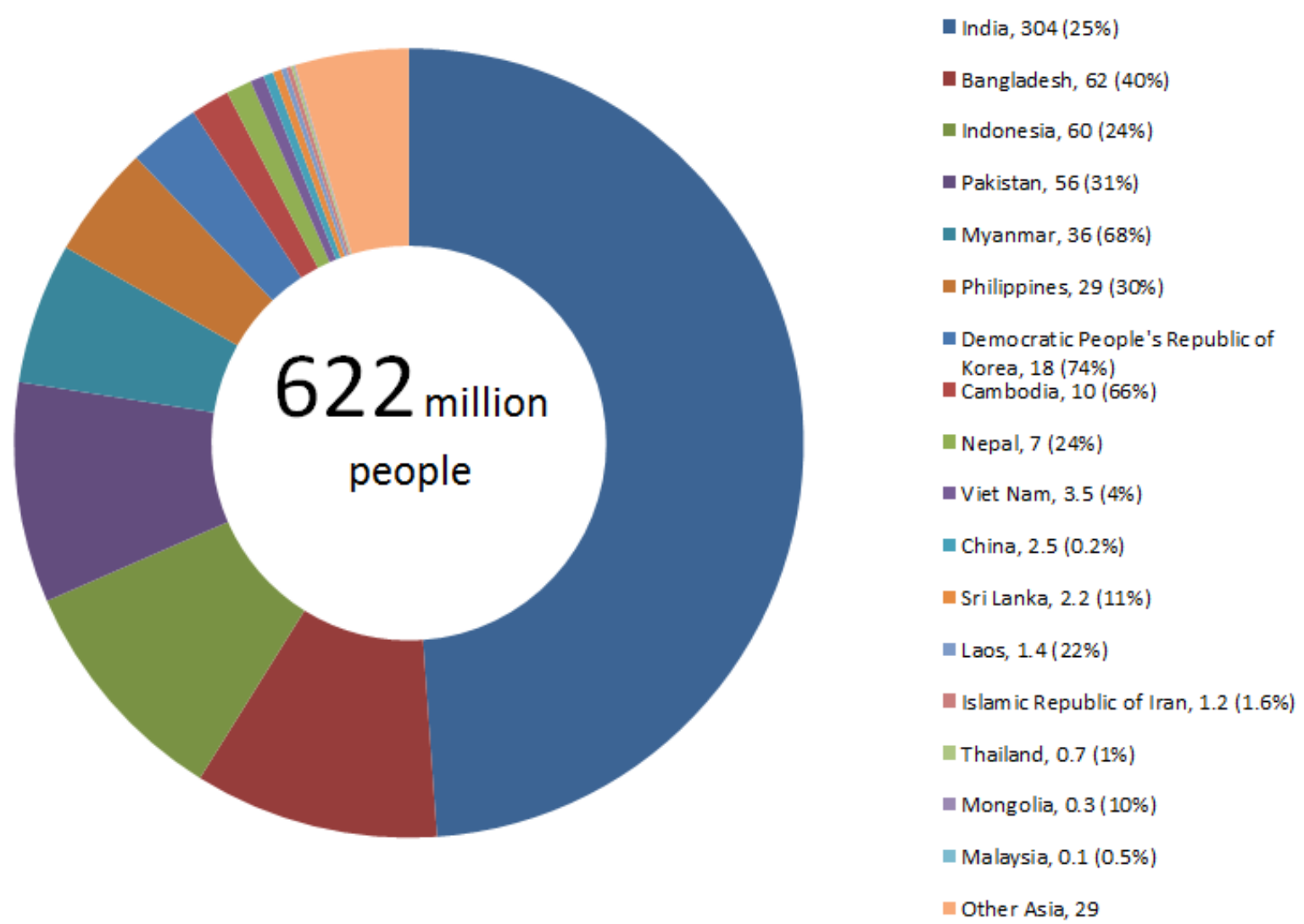

Source: ESCAP's Regional Trends Report on Energy for Sustainable Development in Asia and the Pacific 2015 edition (Based on EIA 2014)

Despite the obvious benefits of enhanced energy trade between Central and South Asia and participating members of the Asia-Pacific Trade Agreement, flows have been rather limited. China, being an exception, imported significant quantities of oil (22\%) and gas (45\%) from the Central and South Asia in 2012 while the Republic of Korea and India imported only 10\% and $9 \%$ of their total oil imports from that subregion, respectively, during that year. On the other side of the spectrum, Sri Lanka and Bangladesh have yet to diversify their energy imports. Sri Lanka imports most of its gas from Oman and most of its coal from Indonesia. The gas imports of Bangladesh predominately come from South-East Asia. Moreover, half of the oil imports of Sri Lanka is sourced from the Middle East, with the other half coming from the Islamic Republic of Iran, whereas all of the oil imports of Bangladesh come from the Middle East. Thus, there is a tremendous potential for the participating member of the AsiaPacific Trade Agreement to diversity their energy mix with imports from countries in Central and South Asia. In sections 3.3. - 3.6., the export and import partners of the participating members of the Asia-Pacific Trade Agreement are shown. 


\subsection{Import of gas by APTA members}

Figure 16 shows the source of gas import in China, India, Republic of Korea, Sri Lanka and Bangladesh where the highest amount of import is in the Republic of Korea and the lowest amount of imports in Bangladesh. Also, while other jurisdictions have the gas imports from several other countries, Sri Lanka has the imports of gas only from Oman.

Figure 16: Sources of APTA members' gas imports

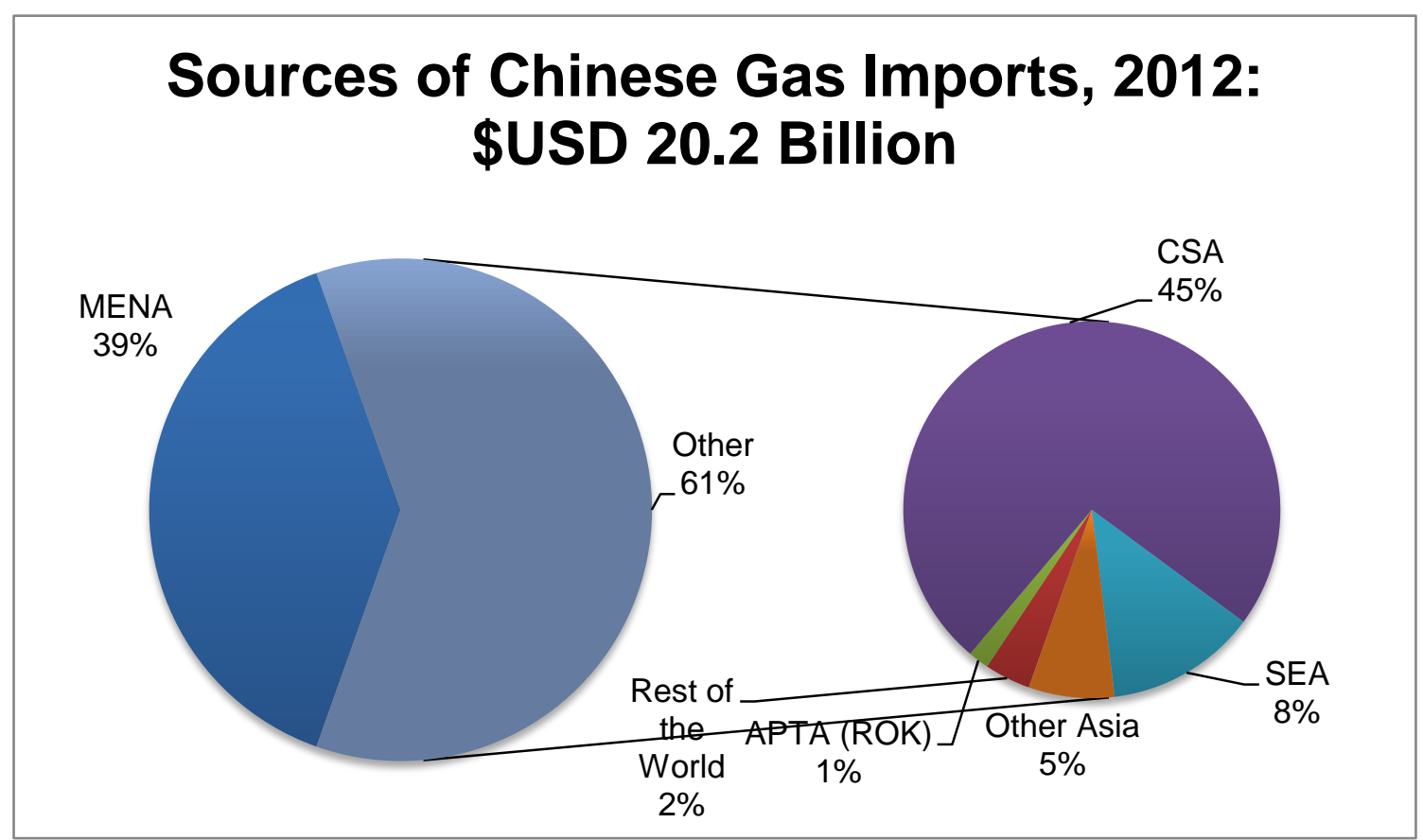

\section{Sources of Indian Gas Imports, 2012: \$USD 14 Billion}

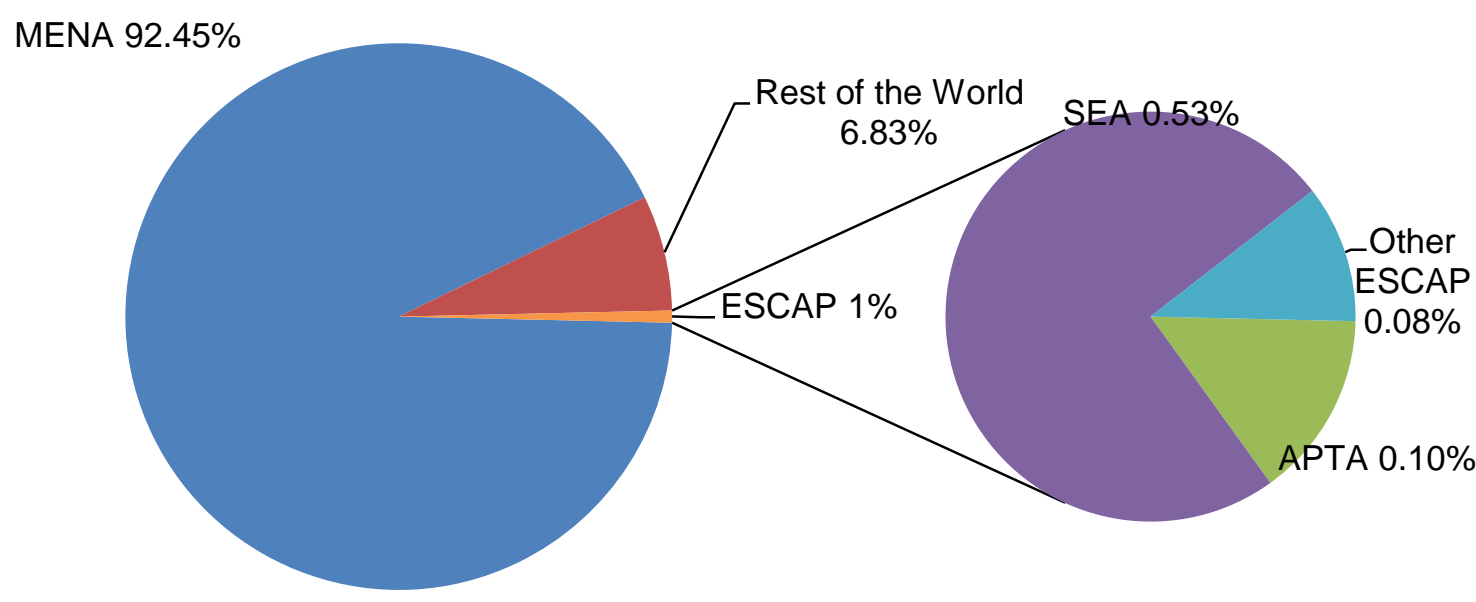




\section{Sources of Republic of Korean Gas Imports, 2012: \$USD 33.8 Billion}

Rest of the World

$8 \%$

Other ESCAP 3\%

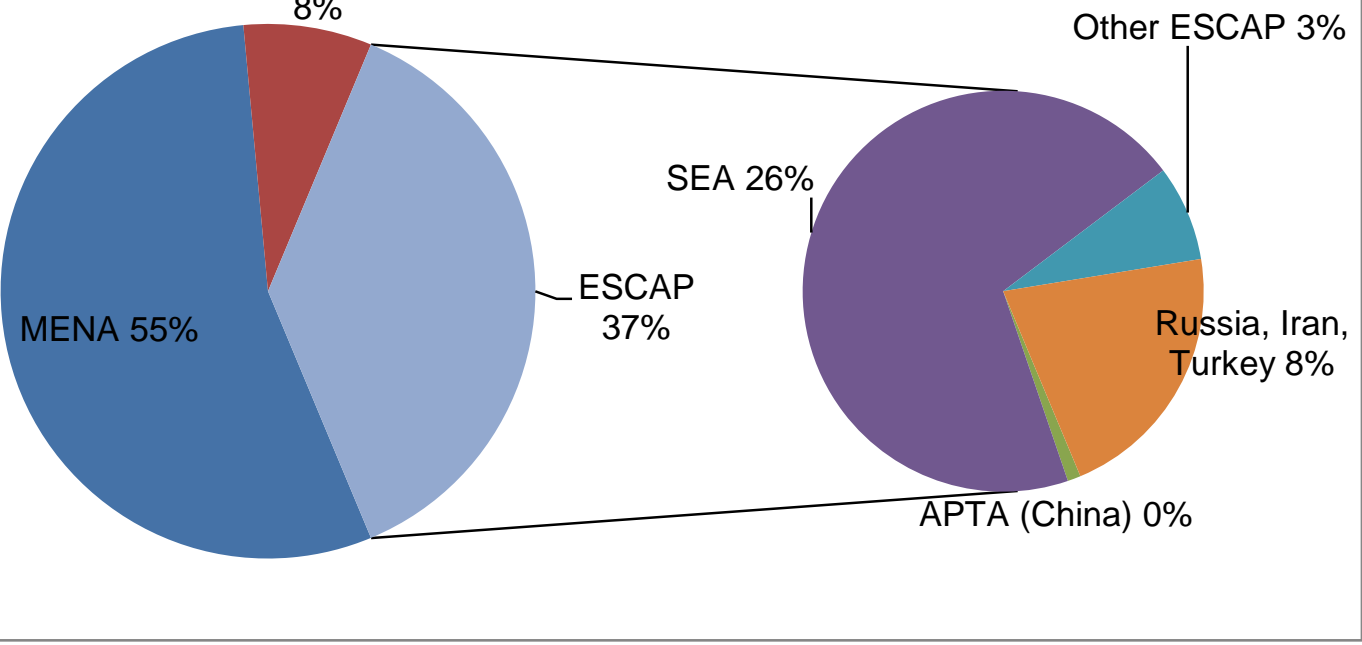

Sources of Sri Lankan Gas Imports, 2012: \$USD 218.8 Million

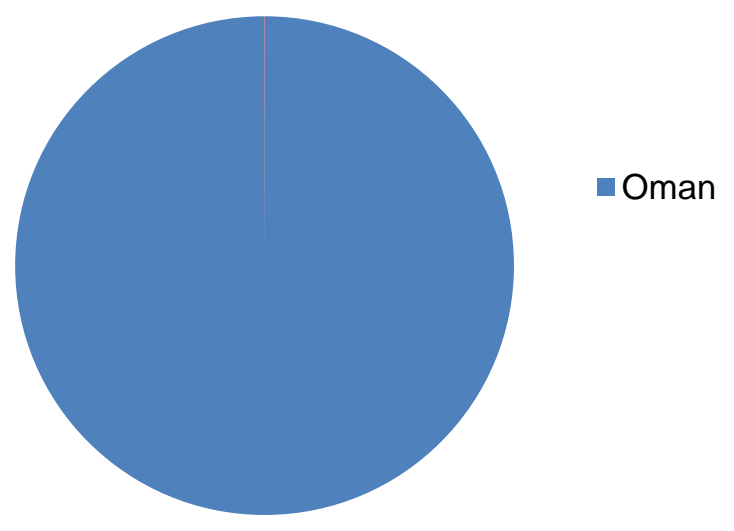




\section{Sources of Bangladesh Gas Imports 2007: \$USD 9.68 Million}

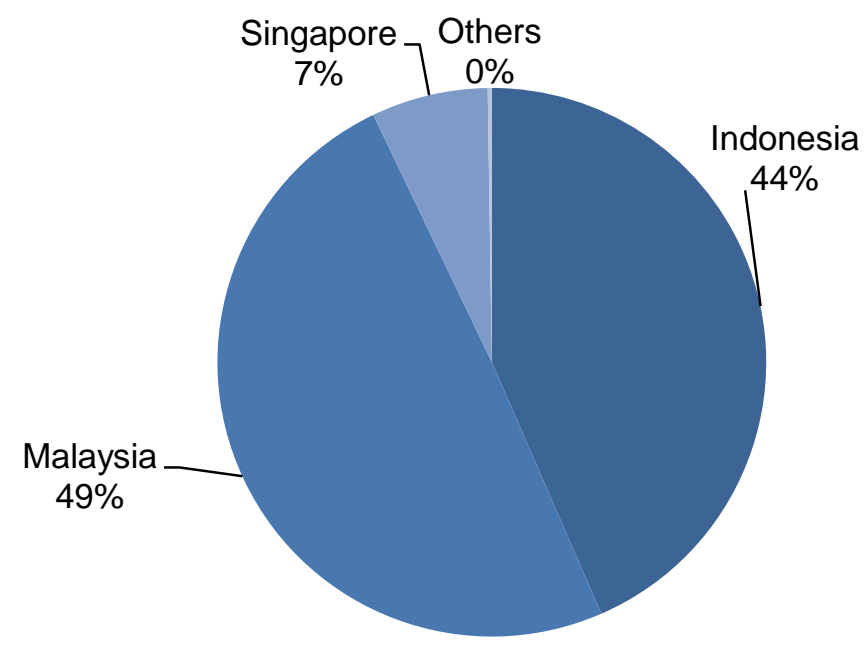

Source: Authors' calculation, based on United Nations Comtrade data downloaded from WITS database (accessed November 2013).

\subsection{Import of oil by APTA members}

There are several countries which have been the sources of oil import to APTA members but figure 17 shows that the Middle East and North Africa have been the countries with the highest export of oil to APTA member especially to the Republic of Korea.

Figure 17: Sources of APTA members' oil imports

\section{Sources of Chinese Oil Imports, 2012}

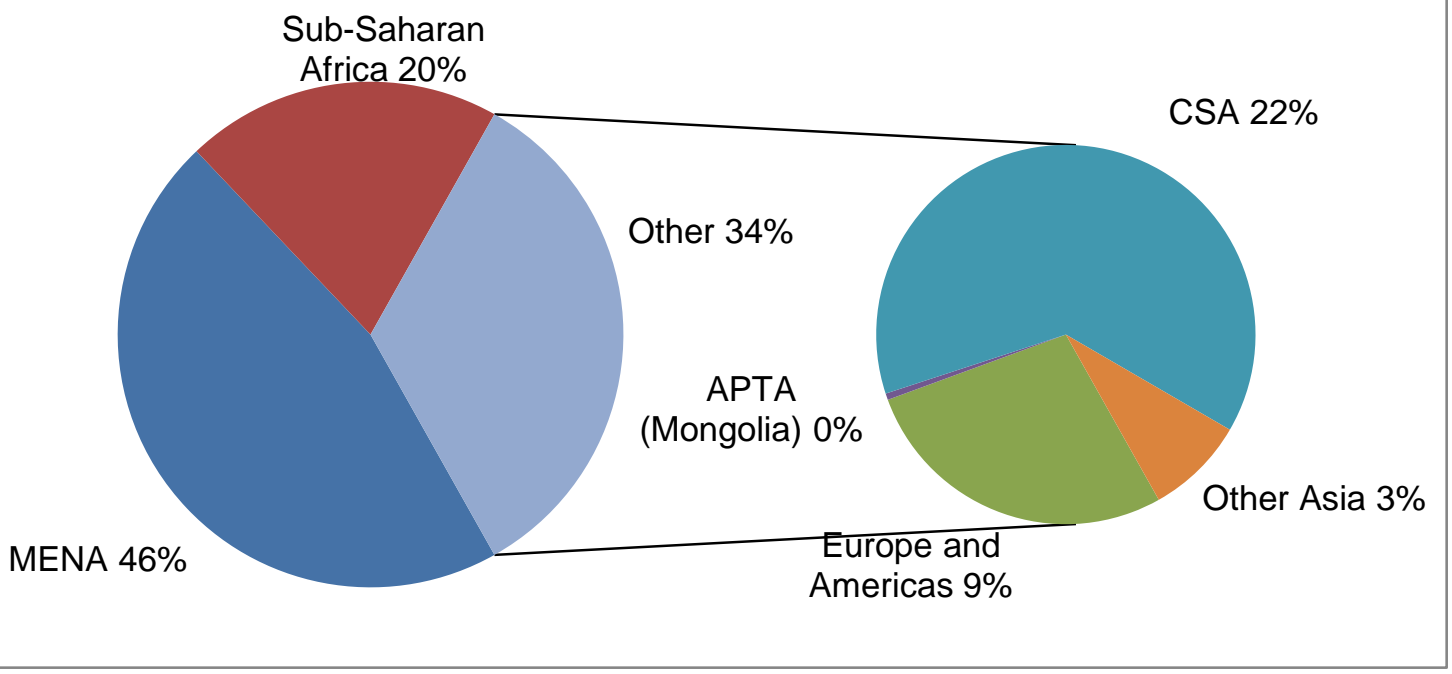




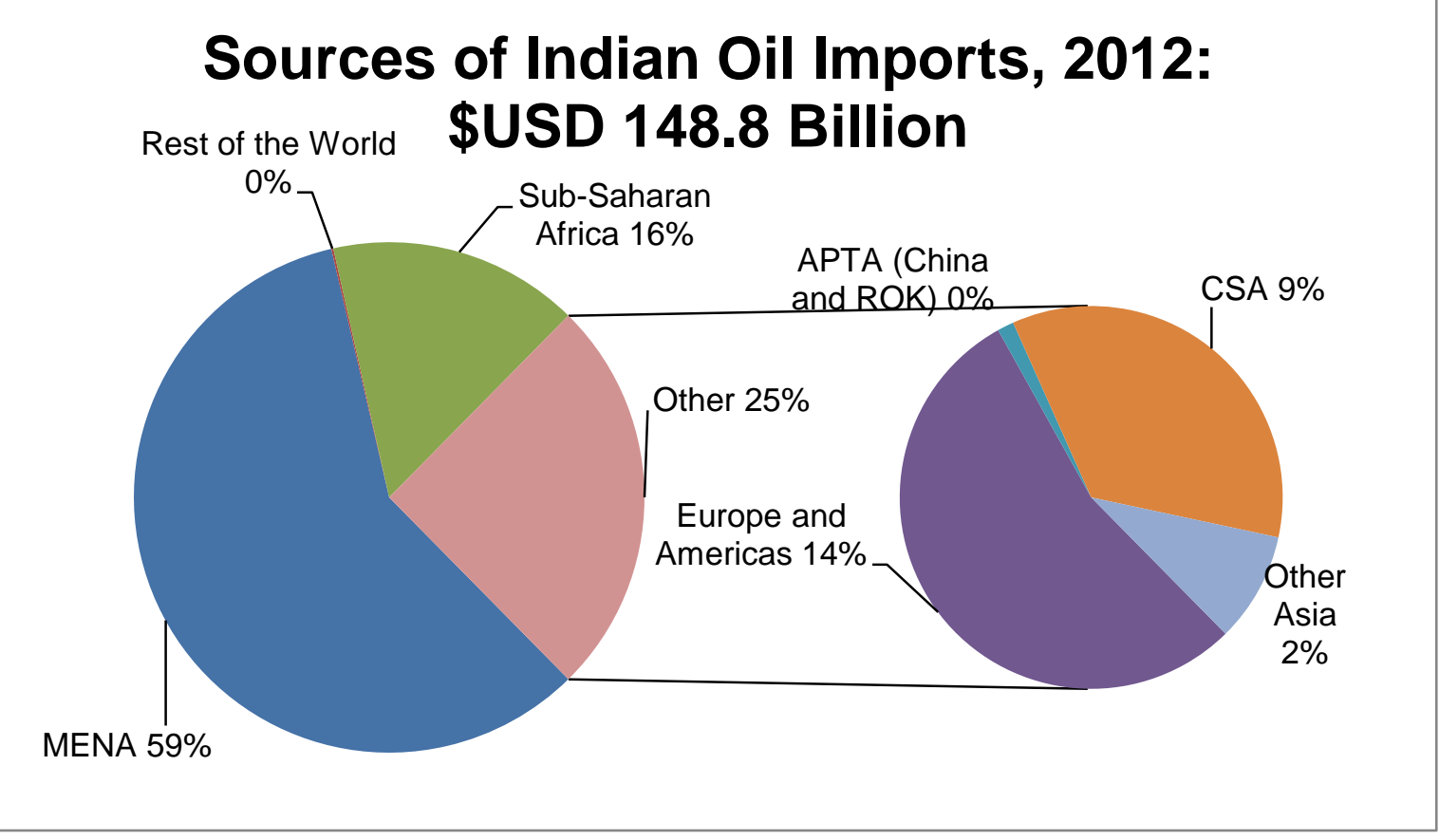

\section{Sources of Republic of Korean Oil Imports, 2012: \$USD 108.3 Billion}

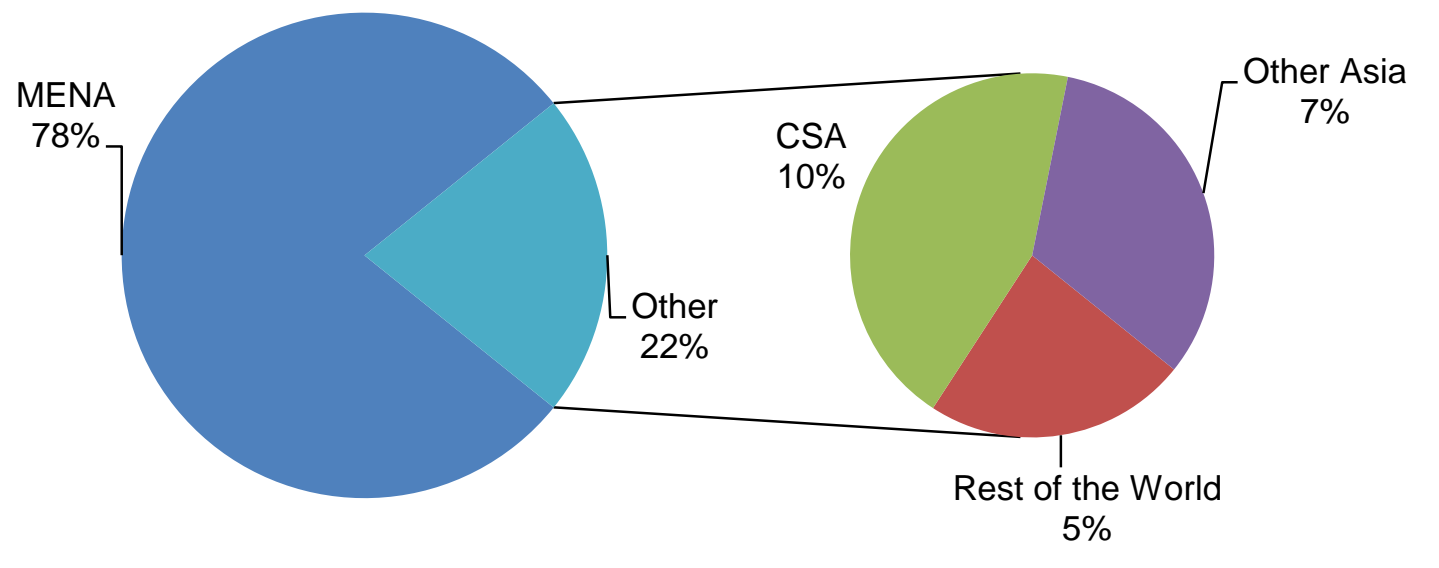




\section{Sources of Sri Lankan Oil Imports, 2012: \$USD 1.3 Billion}
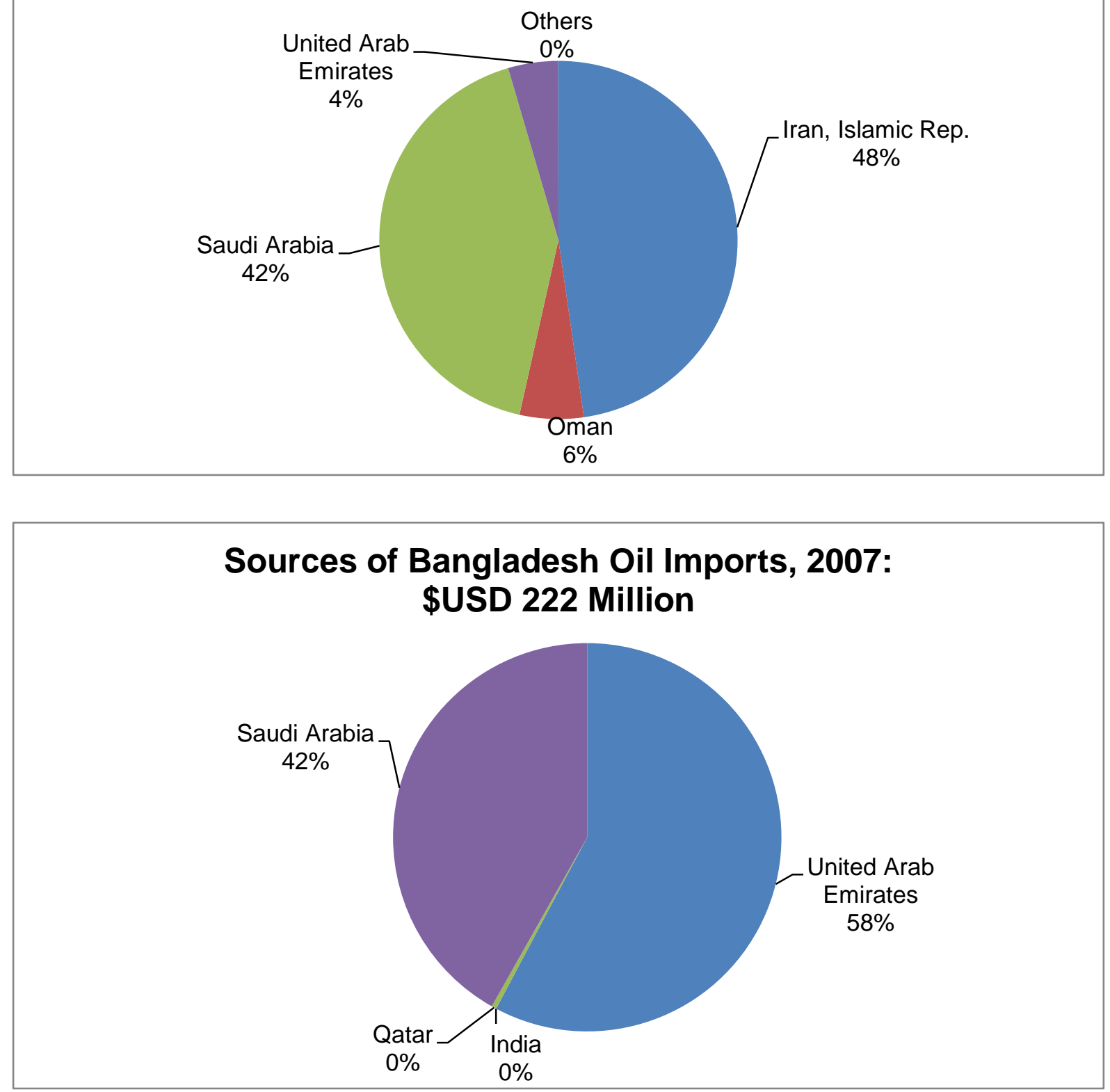

Source: Authors' calculation, based on United Nations Comtrade data downloaded from WITS database (accessed November 2013).

\subsection{Import of coal by APTA members}

Figure 18 shows the source of coal import to APTA members in 2012 which came mostly from ESCAP member countries especially in China and India. The import of more than $80 \%$ of coal to APTA members was from ESCP member countries. In Sri Lanka, the highest coal import was from Indonesia and China was the highest export of coal to Bangladesh. 
Figure 18: Sources of APTA members' coal imports

\section{Sources of Chinese Coal Imports, 2012: \$USD 25.3 Billion}

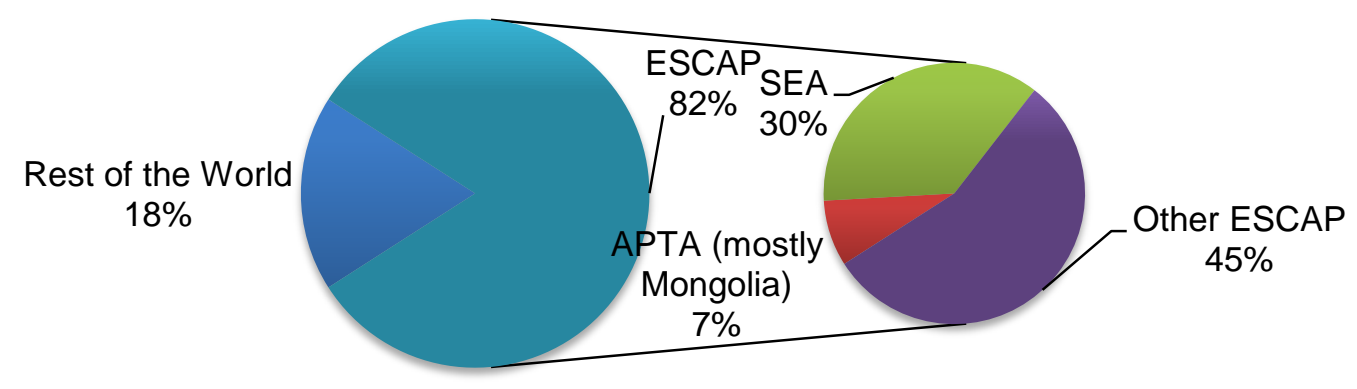

\section{Sources of Indian Coal Imports, 2012: \$USD 15.1 Billion}

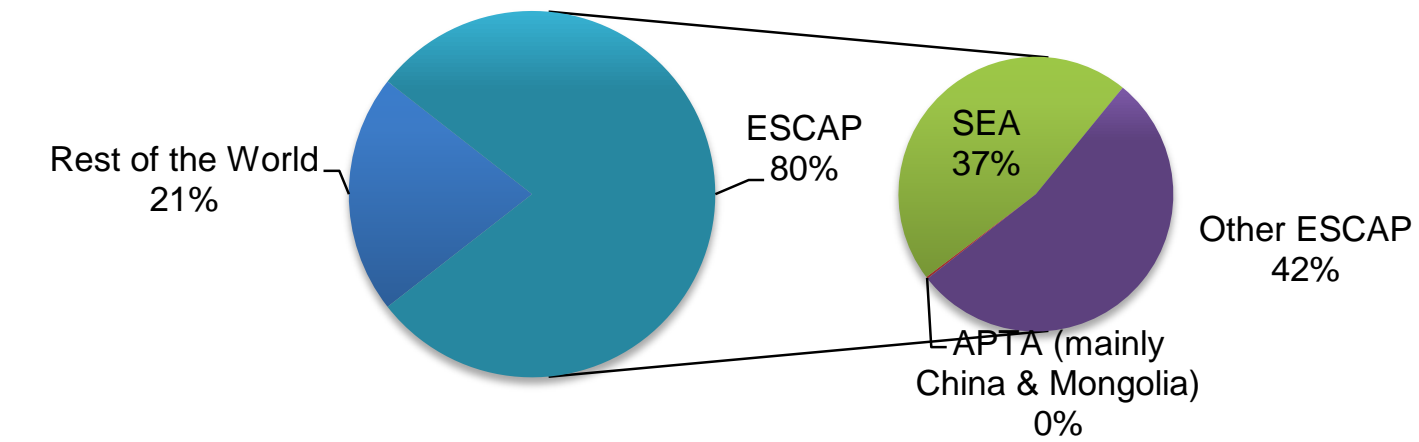

\section{Sources of Republic of Korean Coal Imports, 2012: \$USD 15.9 Billion}

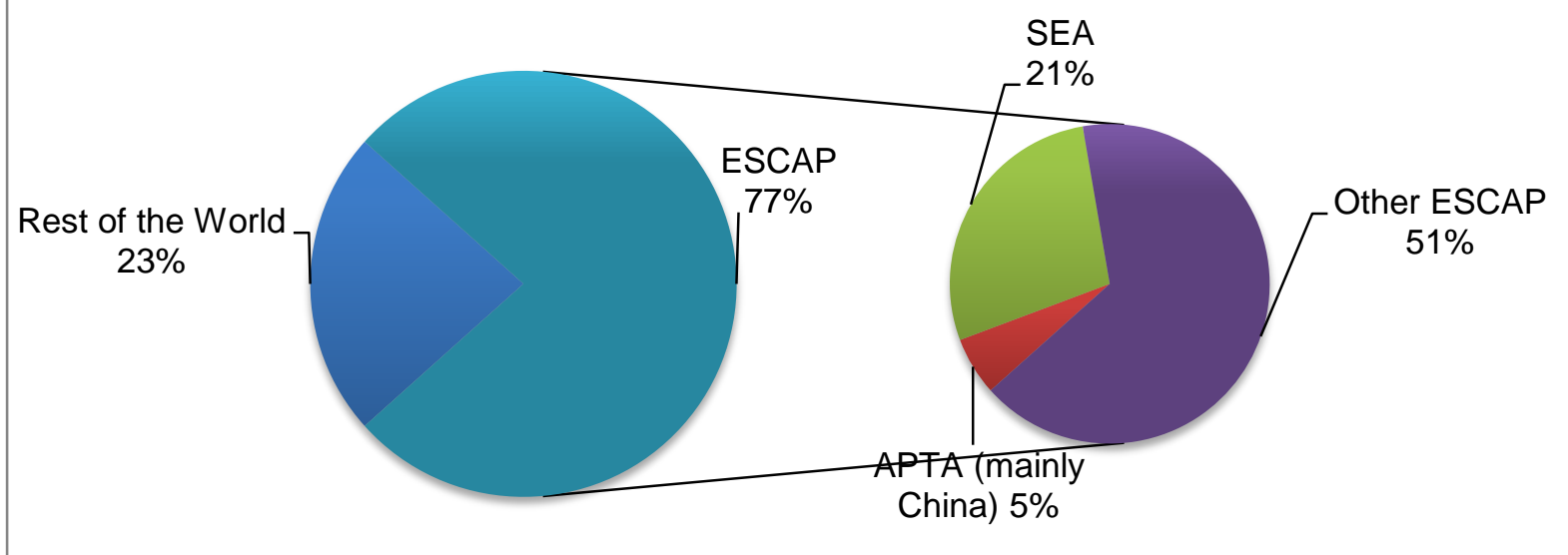




\section{Sources of Sri Lankan Coal Imports, 2012: \$USD 119.5 Million}

Others

$0.16 \%$

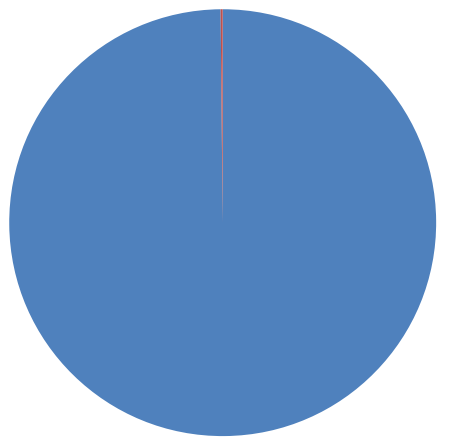

\section{Sources of Bangladesh Coal Imports, 2007: \$USD 37,900}

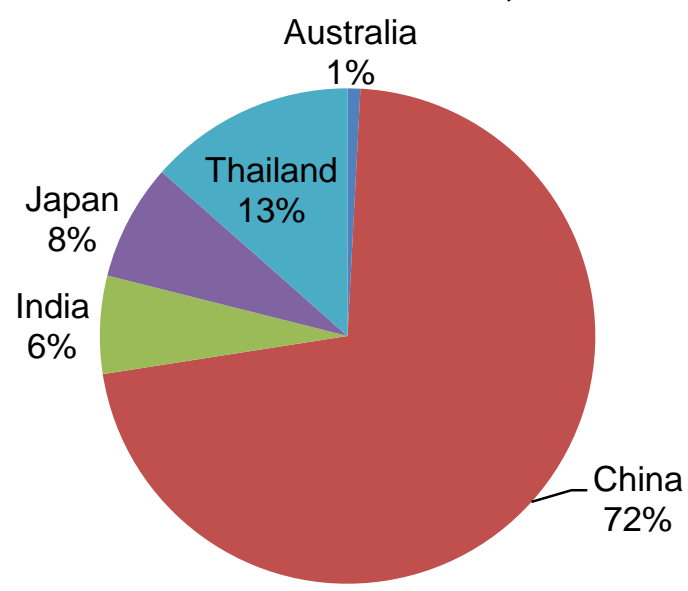

Source: ESCAP calculation, based on United Nations Comtrade data downloaded from WITS database (accessed November 2013).

\subsection{Import of electricity by APTA members}

Figure 19 shows the import of electricity for APTA members where the highest import in 2011 was by Honk Kong, China totaling 60\% followed by Myanmar with 22\%. However, this number was changed in 2012 where Hong Kong, China remained as the highest import of electricity totaling $46 \%$ but it decreased from 2011. In the second place was Russian Federation with 35\% which was higher than in 2011. 


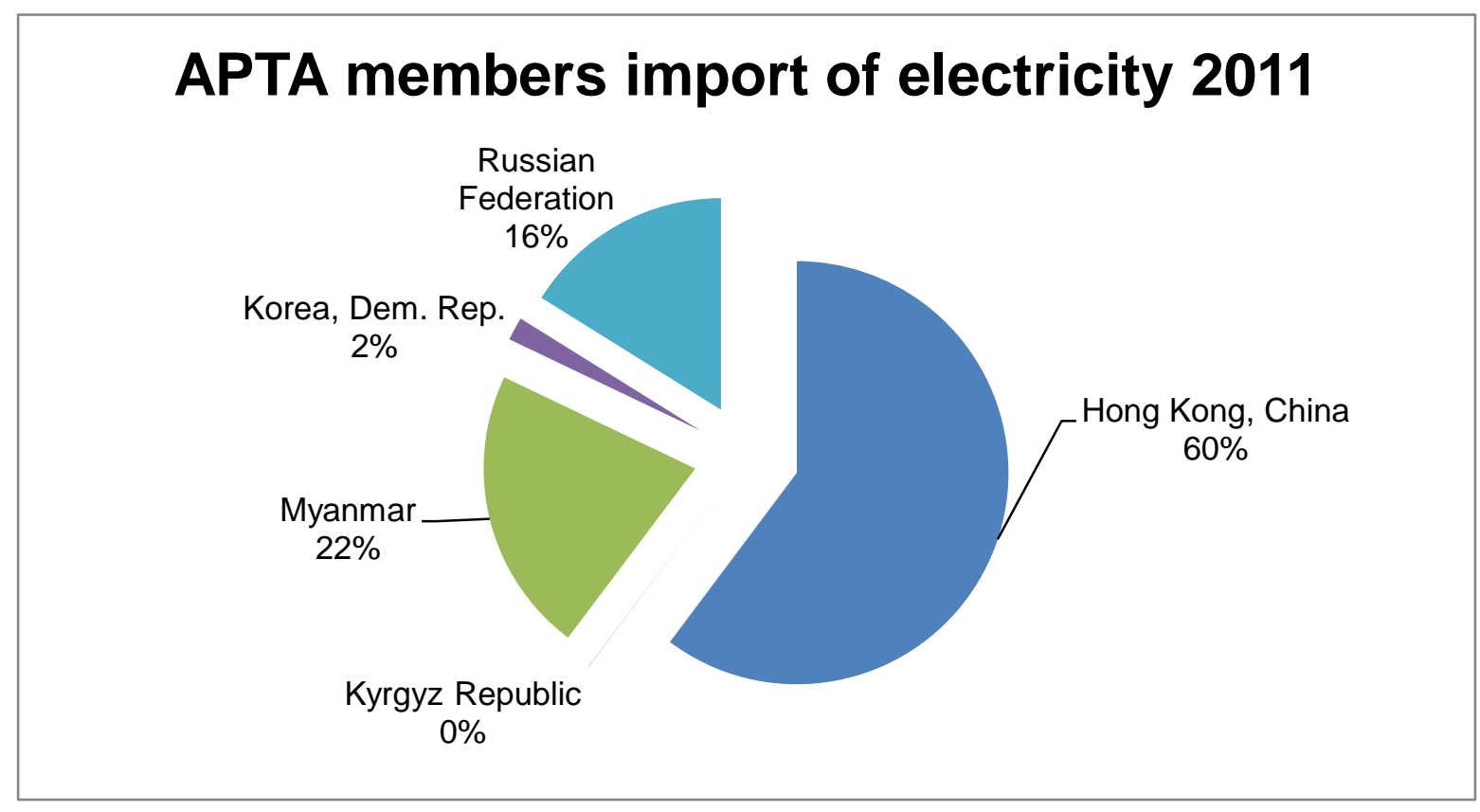

\section{APTA members import of electricity 2012}

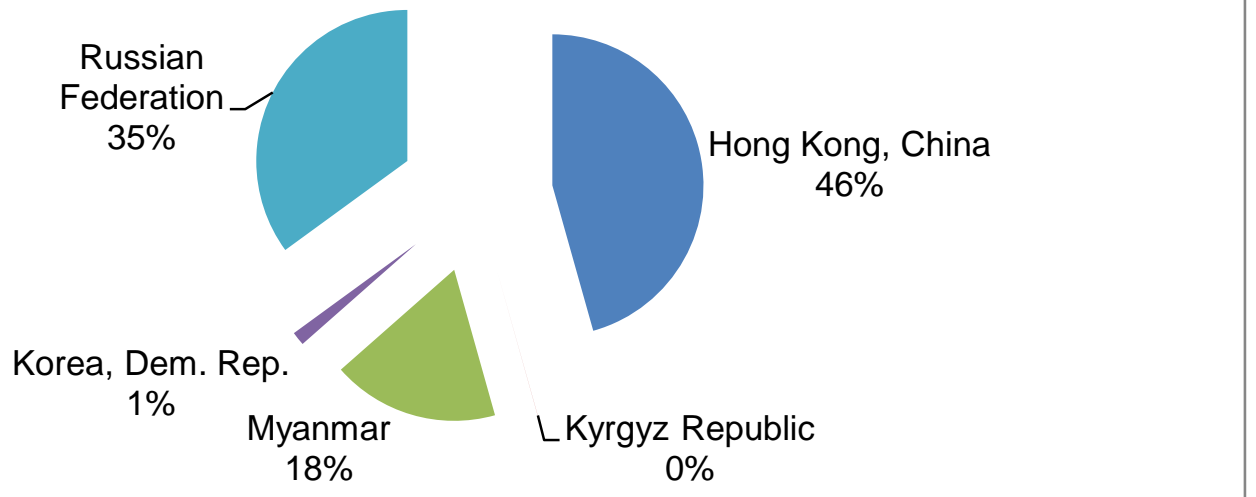

Source: ESCAP calculation, based on United Nations Comtrade data downloaded from WITS database (accessed November 2013).

In contrast to its dependence on fossil fuels imports, China is a net exporter of electricity. It has a reciprocal electricity trading relationship with Hong Kong, China, Myanmar, and the Democratic People's Republic of Korea. As per the 2012 data, some 54\% of the country's electricity exports went to Hong Kong, China, while $46 \%$ of its imports came from Hong Kong, China. Viet Nam and Macau, China are the other major export destinations of the country's electricity. China also supplies electricity in smaller quantities to the Democratic 
People's Republic of Korea, the Lao People's Democratic Republic, Mongolia, and Myanmar. More than half $(53 \%)$ of the electricity exports from China were taken by the Russian Federation and Myanmar Also of note, if the country's electricity exports to its special administration regions of Macau, China and Hong Kong, China, China are not counted, it would have been a borderline net electricity importer by about $\$ 17.34$ Million.

Electricity is not a physical good. Consequently capturing trade data on it more complex compared to oil, gas, and coal. Other than China data on electricity are limited for participating countries of the Asia-Pacific Trade Agreement. However, for the Lao People's Democratic Republic, it is possible to derive trade figures trade data of Thailand. In 2012, the Lao People's Democratic Republic exported about $\$ 797,497$ million of electricity to Thailand, which represents $99 \%$ of its electricity imports. Conversely, the country imported about $\$ 70.7$ million of electricity from Thailand, or $45 \%$ of total electricity export of Thailand. This shows he successful bilateral connectivity that exists between these two countries. The bilateral trade also is reflective of supply of electricity in different geographical regions within the country - one province is recipient while the other is a supplier. With the implementation of the ASEAN Power Grid Project, electricity trade of the Lao People's Democratic Republic with Thailand, as well as with the rest of ASEAN is expected to increase.

It appears that the Republic of Korea is self-sufficient with regard to electricity generation. This probably explains its high household electricity tariffs as shown in figure 20.

Figure 20: Household electricity tariffs for selected ESCAP member states, September 2010

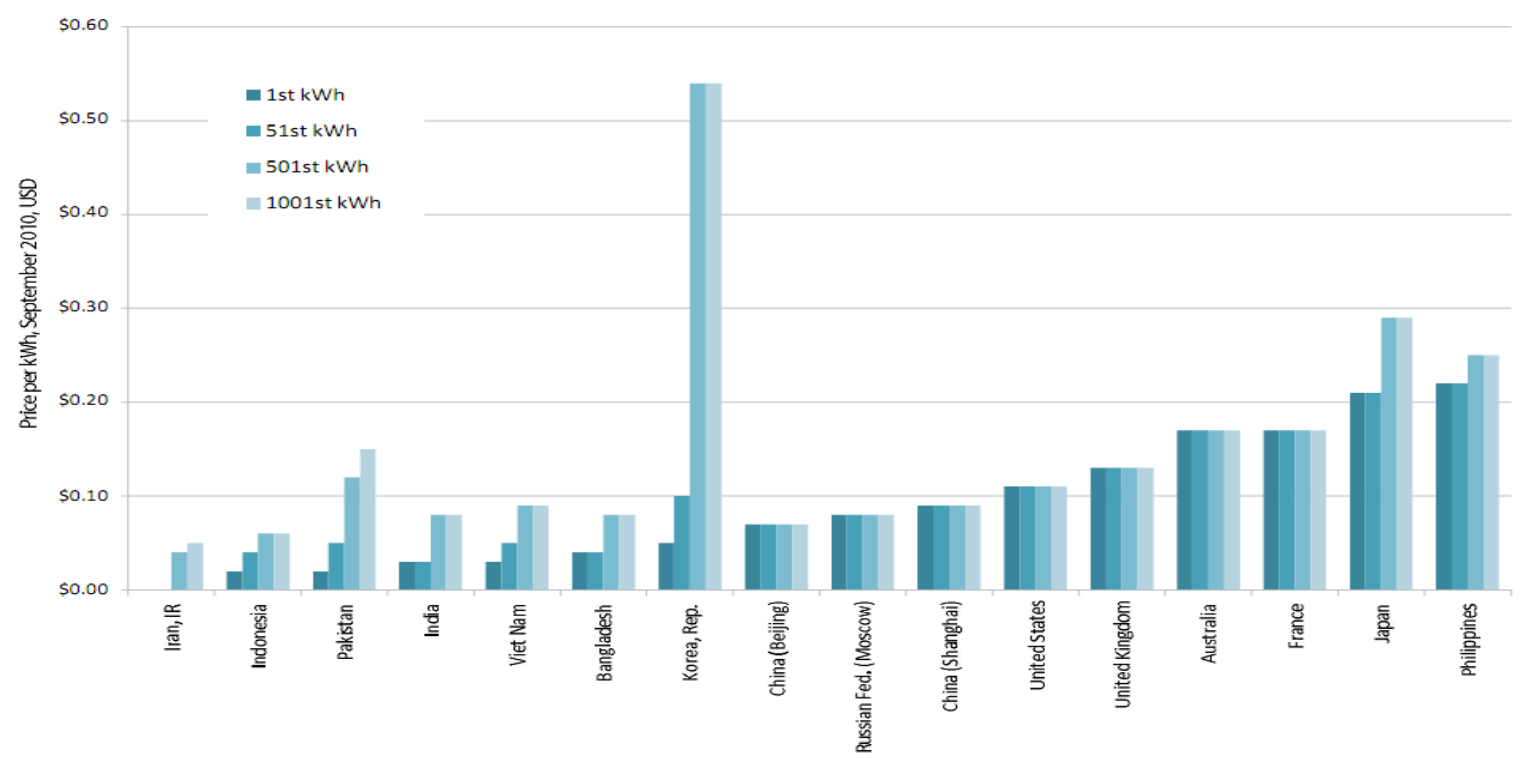

Source: ESCAP Statistical Perspectives, Asia-Pacific Energy Forum (2013b), data were taken from GTZ Power in G20. 
Recognizing that spatial grid integration can bring benefits in enhancing reliability and affordability, extensive plans to boost electricity trade have been undertaken within and across most of the ESCAP subregions. Notably, within the regions covered in the Greater Mekong Subregion and ASEAN. Similarly, such an initiative could also be undertaken in participating members of the Asia-Pacific Trade Agreement, together with North-Central Asian countries.

\subsection{Implication for accession of selected Central and South Asian countries to APTA}

The Central and South Asian countries that are key players in energy trade comprise Armenia, Azerbaijan, Georgia, the Islamic Republic of Iran, Kazakhstan, Kyrgyzstan, Tajikistan, Turkey, Turkmenistan and Uzbekistan.

Notwithstanding the fact that export diversification for those countries is becoming increasingly important with Europe, as their traditional market, gradually moves towards a renewable path, Central and South Asian countries could also benefit from the geographical proximity, regional connectivity and climate synergy of trading their energy resources with Asia and the Pacific, especially if they were to get preferential market access to the participating members of the Asia-Pacific Trade Agreement. Central Asian countries also face unique geopolitical circumstances, particularly the landlocked countries located between the Russian Federation and the Islamic Republic of Iran, the two dominant energy players. The coastal States have strong interests in ensuring their continued energy dominance and that exports from Central Asia would not bypass them. Thus, Central Asian countries might face less geopolitical resistance if they were to send their energy exports to the connected countries near to them. The Asia-Pacific Trade Agreement provides them this opportunity to exploit the situation to their advantage. To do this, they would need to consider acceding to the agreement as members. The process of accession is as follows:

Table 5: Accession process to Asia-Pacific Trade Agreement

\begin{tabular}{|c|l|}
\hline Step & \multicolumn{1}{|c|}{ Action } \\
\hline 1 & $\begin{array}{l}\text { An applicant country notifies the Executive Secretary (ES) of ESCAP of } \\
\text { its intention to accede to the Agreement. }\end{array}$ \\
\hline 2 & $\begin{array}{l}\text { ES informs the existing members of that intention, and the ESCAP } \\
\text { secretariat prepares a programme of negotiations for approval by the } \\
\text { members. }\end{array}$ \\
\hline
\end{tabular}




\begin{tabular}{|c|c|}
\hline 3 & Bilateral negotiations \\
\hline 4 & Multilateralization of agreed concessions \\
\hline 5 & $\begin{array}{l}\text { The Agreement comes into force for an eligible acceding country on the } \\
\text { date of deposit of its corresponding instrument of accession, accompanie } \\
d \text { by the National List of Concessions and the related administrative notifi } \\
\text { cation (e.g. a government notification, such as a customs notification) } \\
\text { with the ES of ESCAP. }\end{array}$ \\
\hline
\end{tabular}

Source: Asia-Pacific Trade Agreement Brochure, ESCAP.

As mentioned above, the Central and South Asian subregion dominates electricity trade in Asia and the Pacific. There is vast potential to develop a power exchange relationship involving the subregion and some of the member countries of the Asia-Pacific Trade Agreement, specifically China and India, given their geographic proximity to the subregion. Electricity cooperation already exists among the Kyrgyz Republic, Tajikistan, Pakistan and Afghanistan under the CASA-1000 electricity transmission system project. The project aims to transfer electricity from hydropower facilities in the Kyrgyz Republic and Tajikistan to electricity consumers in Afghanistan and Pakistan (CASA-1000, 2011). Hence, the surplus generation in Central and South Asian countries during summer months can be channeled for a profit to offset power shortages that frequently occur in Pakistan and Afghanistan during the summer. The difference in climate conditions in the two subregions - some countries in Central and South Asia are only prone to power shortages during winter, as opposed to South Asia, which requires more electricity during summer- created an opportunity for mutual gains.

Another major challenge for the countries of Central and South Asia that can be addressed through deepening their engagement with participating members of the Asia-Pacific Trade Agreement is energy intensity. Energy intensity refers to the energy required to produce a unit of GDP. It is used to measure energy efficiency and conservation. As mentioned in the ADB Asia-Pacific Energy Outlook 2013, energy efficiency and conservation is a means to enhance energy supply security, especially for countries facing limited resources. It is affected by various factors, including industry structure, technology, lifestyle and climate conditions. In addition, energy prices as well as access to infrastructure can also affect energy intensity

Energy intensity in the Asia-Pacific region is very high, representing two-thirds of global energy intensity in 2010, mainly owing to North and Central Asian countries. The subregion 
displays the highest energy intensity, about 1.75 times that of the average for ESCAP countries ESCAP average, making it highly energy inefficient. Energy efficiency is positively correlated with economic competitiveness. Thus, economic development in Central South Asian countries, such as Armenia, the Islamic Republic of Iran, Kazakhstan, Kyrgyzstan and Tajikistan hampered by energy usage inefficiencies (figure 21).

By acceding to Asia-Pacific Trade Agreement, the countries of Central and South Asian countries could benefit from technology transfer to ameliorate their energy efficiency performance as it would facilitate hard and sift technologies to be transferred from APTA members namely China, India and the Republic of Korea. The framework agreements on trade in services, trade facilitation and investment once implemented would promote intraregional investment flows, establishing backward-forward linkages between industries and regional supply chain. The higher trade volumes resulting from the agreements will generate greater domestic economic activity to meet the developmental objectives of the countries of Central and South Asia. In addition, given that tariff concessions are offered on numerous items, the Central South Asian countries could diversify their export commodities to participating members of the Asia-Pacific Trade Agreement to include miscellaneous other products (non-energy related) and services.

Figure 21: Energy efficiency and economic competitiveness, ${ }^{11} 2010$.

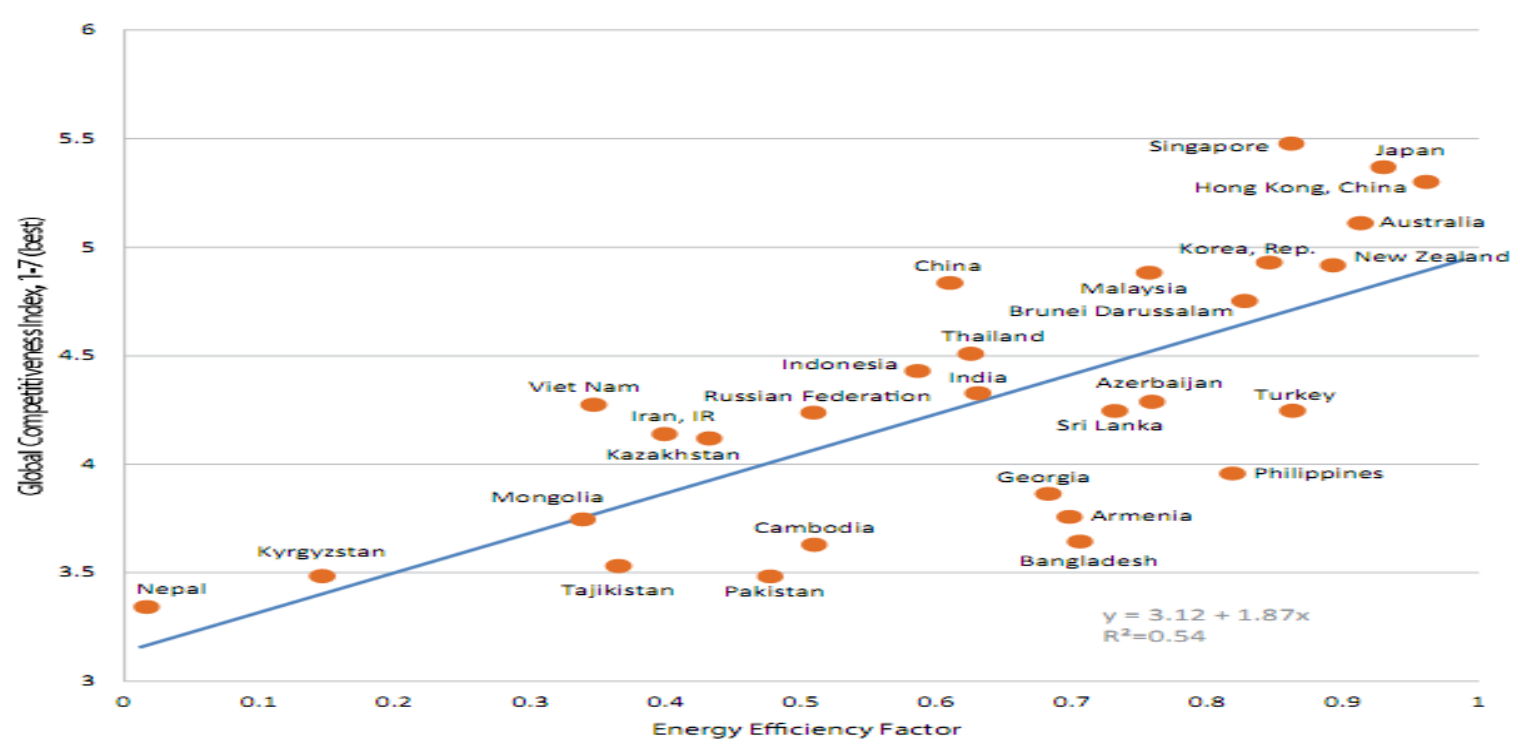

Source: ESCAP Statistical Perspectives, Asia-Pacific Energy Forum 2013, data taken from IEA.

\footnotetext{
${ }^{11}$ The Global Competitiveness Index is a composite statistic published annually by the World Economic Forum. The Energy Efficiency Factor is derived from subtracting final energy intensity from 1. A higher value represents greater efficiency.
} 


\section{Conclusion}

Efforts aimed at achieving energy security in Asia and the Pacific have mostly favoured bilateral approaches, with the bulk of energy trade occurring with extra-regional countries. Regional cooperation has occurred mainly within established subregional groupings, such as ASEAN. As a result, periphery countries have largely been marginalized even though such countries tend to possess rich resources. This present report has also shown that there is vast potential for synergistic gains to be achieved through intraregional trade pacts that are backed up with energy security goals.

The Asia-Pacific Trade Agreement is poised to serve as a framework for effective cooperation in energy trade. Not only does it span East and South Asia to include least developed countries together with the three major economies in the region, it is also the only operational trade agreement linking the economic powerhouses of China and India. Under the fourth round negotiations, tariff concessions have been both widened and deepened for more than 10,000 mutual-interest items (ESCAP, 2013a). There are also certain items relating to energy that are already present in this concession list, thus providing a foundation for the expansion of energy trade.

Although the present paper has not analysed clean technology and renewable energies in detail, through the Agreement, there are potential gains for both participating members and Central and South Asian countries with regard to clean energy technology transfers and harmonizing of power grids to overcome the problem of intermittency in using renewable energy sources. Asia and the Pacific are considered the most dynamic region in terms of application of climate-smart goods and technologies (ESCAP, 2011a) ${ }^{12}$, with the Participating States of the Asia-Pacific Trade Agreement leading the way. Hence, there exists a mutually beneficial opportunity for consolidated trade cooperation. According to a report by the Pew Research Center, China "advanced its position as the epicenter of clean energy finance" in 2012 and the Asia-Pacific region became the "leading regional destination for clean energy financing" amid a decline in other parts of the world (The Pew Charitable Trusts, 2013). Thus, the strategic combination of fossil fuels and clean/renewable energies can forge a clear path for a sustainable energy transition for both participating countries of the Asia-Pacific Trade Agreement and Central and South Asian countries without sacrificing growth.

In view of the above analysis of trends, Central and South Asian countries and participating members of the Asia-Pacific Trade Agreement should consider jointly working towards

\footnotetext{
${ }^{12}$ Over the period 2002-2008, imports of climate-smart goods and technologies rose six times.
} 
expanding the Agreement's membership to attain a 'win-win' situation for energy trade and energy security. As the Agreement is open-ended, it is easy for any ESCAP member to seek accession, which would also facilitate the free flow of goods and technological know-how for creating energy efficiency. 


\section{References}

Asian Development Bank (ADB) (2013). Energy Outlook for Asia and the Pacific. Available from www.adb.org/sites/default/files/pub/2013/energy-outlook.pdf

BP (2013). BP Statistical Review of World Energy. Available from www.bp.com/content/dam/bp/excel/Statistical-

review/statistical_review_of_world_energy_2013_workbook.xlsx.

CASA-1000 (2001). CASA-1000 Project.List of FAQs. June 6. Available from www.casa1000.org/1.\%20Project_FAQs_ENG.pdf

Energy Charter. Members and Observers. Available from www.encharter.org/index.php?id=61

Favennec, Jean-Pierre (2011). The Geopolitics of Energy. Paris: IFP Energies Nouvelles.

International Energy Agency (IEA) (2013). World Energy Outlook 2013 factsheet: How will global energy markets evolve to 2035?. Available from www.worldenergyoutlook.org/media/weowebsite/factsheets/WEO2013 Factsheets.p df.

(2015) EIA. 2015. International Energy Statistics. Available at:

http://www.eia.gov/forecasts/aeo/

JODI (2013). Historical background: JODI and oil data. Available from https://www.jodidata.org/about-jodi/history.aspx

The Pew Charitable Trusts (2013). Who's Winning the Clean Energy Race? 2012 ed.

United Nations, Economic and Social Commission for Asia and the Pacific (ESCAP) (2011a). Asia-Pacific Trade and Investment Report 2011. United Nations publication, Sales No. E. 11.II.F.8.

(2013a) Asia-Pacific Trade and Investment Report 2013:

(2013b) Statistical Perspectives: Focus Areas for Enhanced Energy Security. ST/ESCAP/2662. Prepared as an input to the Asia-Pacific Energy Forum, Vladivostok, Russian Federation, 27-30 May, 2013. Available from www.unescap.org/sites/default/files/UN-Stats-Booklet-final $\quad 0 . p d f$ 
(2014) Regional Connectivity and Shared Prosperity, United Nations publication, Bangkok. Sales No. E. 14.II.F.4

(2015a) Survey of Asia and the Pacific 2015 - Part I, United Nations publication, Bangkok. Sales No. E. 15.II.F.7

(2015b) Saggu, Aman and Anukoonwattaka, Witada. Global Commodity Price Falls: A Transitory Boost to Economic Growth in Asia-Pacific Countries with Special Needs (Trade Insights: Issue No. 8), March 2015

(2015c) Saggu, Aman and Anukoonwattaka, Witada. Commodity Price Crash: Risks to Exports and Economic Growth in Asia-Pacific LDCs and LLDCs (Trade Insights: Issue No. 6) March 2015

(2015d) Regional Trends Report on Energy for Sustainable Development in Asia and the Pacific 2015 edition

United States, Energy Information Administration (EIA) (2013). International Energy Statistics. Available from www.eia.gov/cfappa/ipdbproject/iedindex3.cfm.

World Bank (2013). World Integrated Trade Solution (WITS). Available from wits.worldbank.org. 


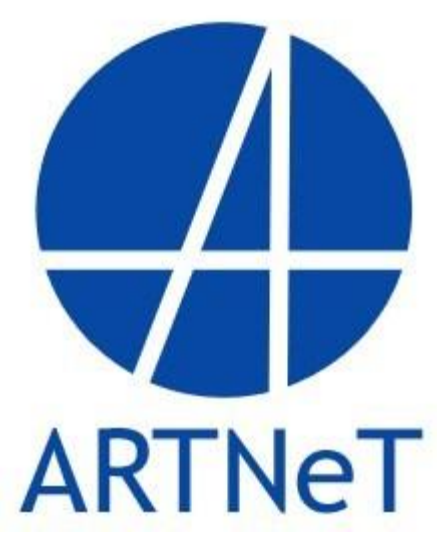

The Asia-Pacific Research and Training Network on TradeARTNeT- is an open network of research and academic institutions and think-tanks in the Asia-Pacific region, established by core partners IDRC, ESCAP, UNCTAD, UNDP and WTO. ARTNeT aims to increase the amount of high quality, topical and applied research in the region by harnessing existent research capacity and developing new capacities. ARTNeT also focuses on communicating these research outputs for policymaking in the region including through the ARTNeT Working Paper Series which provide new and policy-relevant research on topics related to trade, investment and development. The views expressed in this publication are those of the authors and do not necessarily reflect the views of the United Nations and ARTNeT secretariat or ARTNeT members.

Readers are encouraged to quote or reproduce material from ARTNeT Working Papers for their own publications, but as the copyright holder, ARTNeT requests due acknowledgement and a copy of the publication.

This and other ARTNeT publications are available from

\section{artnet.unescap.org}

ARTNeTontrade

@ARTNeTontrade

ARTNeT Group

artnetontrade@un.org
ARTNeT Secretariat, United Nations ESCAP

Rajadamnern Nok Avenue

Bangkok 10200, Thailand

Tel: $+66(0) 22881410$

Fax: $+66(0) 22881027$ 